\title{
Effect of Substrate Properties and Phosphorus-supply on the Rare Earth Element Facilitation in Mixed-culture Cropping Systems of Hordeum Vulgare, Lupinus Albus and Lupinus Angustifolius
}

Nthati Monei

Tallinn Technical University: Tallinna Tehnikaulikool

Michael Hitch

Western Australia School of Mines

Juliane Heim

TU Bergakademie Freiberg: Technische Universitat Bergakademie Freiberg

Olivier Pourret

UniLaSalle

Hermann Heilmeier

TU Bergakademie Freiberg: Technische Universitat Bergakademie Freiberg

Oliver Wiche ( $\nabla$ oliver.wiche@ioez.tu-freiberg.de )

Technische Universitat Bergakademie Freiberg https://orcid.org/0000-0002-2081-0524

\section{Research Article}

Keywords: Intercropping, rhizosphere, rare earth elements, white lupin, root exudates, phytoextraction

Posted Date: January 3rd, 2022

DOI: https://doi.org/10.21203/rs.3.rs-1111280/v1

License: @ (i) This work is licensed under a Creative Commons Attribution 4.0 International License. Read Full License 


\section{Abstract}

This study presents how nutrient availability and intercropping may influence the migration of REE when cultivated under P-deficient conditions. In a replacement model, Hordeum vulgare was intercropped with $11 \%$ Lupinus albus cv. Feodora and $11 \% \mathrm{~L}$. angustifolius cv. Sonate. They were cultivated on two substrates, $\mathrm{A}(\mathrm{pH}=7.8)$ and $\mathrm{B}(\mathrm{pH}=6.6)$. Two nutrient solutions were supplied, with $\mathrm{N}, \mathrm{K}, \mathrm{Mg}$ and high $\mathrm{P}$-supply $(\mathrm{P}+)$, the other with $\mathrm{N}, \mathrm{K}, \mathrm{Mg}$, and one-third of P-supply (P-, applied to LO and Lan only). Simultaneously, a greenhouse experiment was conducted to quantify carboxylate release. There, one group of $L$. albus and $L$. angustifolius was supplied with $200 \mu \mathrm{M} \mathrm{K}_{2} \mathrm{HPO}_{4}(\mathrm{P}+)$ together with the other nutrients while a second group received $20 \mu \mathrm{M} \mathrm{P}(\mathrm{P}-)$. L. albus released higher carboxylates at low P-supply than $L$. angustifolius. Higher P-supply did not influence the $\mathrm{P}$ concentrations and contents of $H$. vulgare neither on substrate A nor on substrate B. However, addition of $\mathrm{P}$ decreased the concentrations of REEs, especially in plants cultivated on alkaline soil. Nutrient accumulation decreased in $H$. vulgare in intercropping with $L$. angustifolius when cultivated on the alkaline substrate $A$ with high P-supply. In the same conditions, the accumulation of REE in $\mathrm{H}$. vulgare significantly increased. Conversely, on the acidic substrate B intercropping with $L$. albus decreased REE contents and concentrations in $H$. vulgare. Intercropping with $L$. angustifolius opens an opportunity for enhanced phytomining and accumulation of REE. Furthermore, intercropping with L. albus on REE polluted soils may be utilized to restrict REE accumulation in crops used for food production.

\section{Introduction}

Carboxylates released by plant roots are an important strategy of plants to access sparingly available phosphorus and micronutrients such as Fe and Mn in soil (Cu et al. 2005). Particularly for P, Fe and Mn the availability is limited by low solubility of the corresponding element-bearing minerals and interactions with other inorganic and organic soil phases. Specifically, in soils Fe and Mn are present as Fe oxyhydroxides and Mn oxides, characterized by low solubility above a soil pH of 5. Thus in alkaline soils the availability of Fe and $\mathrm{Mn}$ is limited by their extremely low solubility of the respective oxides and oxyhydroxides (Penn and Camberato 2019; Rengel 2015) whereas phosphate strongly interacts with calcium by the formation of hardly soluble Ca-phosphates. Moreover, under acidic soil conditions and below a $\mathrm{pH}$ of 7, $\mathrm{Fe}, \mathrm{Mn}$ and $\mathrm{P}$ often behave in a dual-way showing steadily increasing solubility of Fe and $\mathrm{Mn}$, whereas fixation/specific sorption of phosphate on Fe-oxyhydroxides and aluminium hydroxides increases and leads to accumulation of $\mathrm{P}$ in acidic soils in sparingly plant available forms (Penn and Camberato 2019). Plants adapted to these conditions and evolved towards a self-determined influence on the chemical features surrounding their roots to create an environment which is characterized by optimal biochemical traits for nutrient acquisition (rhizosphere) and ensures adequate nutrient supply over a wide range of soil conditions. Besides mutualistic interactions with bacteria and fungi and alteration of soil physical properties the most important and commonly explored mechanisms include acidification of the rhizosphere by release of protons and release of element-chelating carbon compounds such as carboxylates (Hartman and Tringe 2019; Amadou et al. 2021). The ability for mobilizing $P$ and micronutrients in the rhizosphere varies considerably in dependence on plant species, functional plant groups (Lambers et al. 2013; Lambers et al. 2015; Neumann et al. 2000) or even genotypes in a certain species (Krasilnikoff et al. 2003). Forbs in general and legumes in particular are considered to be Pefficient due to a strong ability to acidify the rhizosphere and release large quantities of carboxylates under $\mathrm{P}$ and $\mathrm{Fe}$ deficiency, while grasses such as Avena sativa and Hordeum vulgare are described as P inefficient (Lambers et al. 2015; Wang et al. 2013). However, under Fe deficiency grasses release a variety of phytosiderophores to cope with Fe deficiency. In fact, release of siderophores is considered a highly efficient mechanism (independent of $\mathrm{pH}$ ) for the acquisition of a variety of different trace metals such as Fe, Cu, Zn, Ni and Co (Marschner et al. 1986; Oburger et al. 2014; Reichman and Parker 2005). Although these processes related to plant nutrition are initially regulated by nutrient deficiency, both strategies must be generally considered non-element-specific with respect to the effects of the chemical processes in the rhizosphere. That means while nutrient deficiency triggers a shift in metabolism towards elevated proton and carboxylate release, the compounds released do not only attack nutrient bearing soil phases but also alter solubility and mobility of 
non-essential elements in the soil. In addition to this, they influence their availability as it has been demonstrated for Cd, $\mathrm{Pb}$ and rare earth elements (REEs) (Wiche et al. 2016a). Among these elements REEs are particularly interesting to study because they i) are present in almost all soils at concentrations comparable to essential plant nutrients, ii) share chemical similarities to essential nutrients, particularly $\mathrm{Ca}$, (iii) interact with nutrient bearing soil minerals (phosphates, Feoxyhydroxides), but (iv) are still not essential to plants nor strongly toxic (Tyler 2004). More specifically, the REEs comprise a group of 17 elements from the lanthanide series including lanthanum, yttrium ( $\mathrm{Y}$ ) and scandium (Sc) that are abundant in the earth crust with concentrations that vary from $66 \mu \mathrm{g} \mathrm{g}^{-1}$ (Ce), $30 \mu \mathrm{g} \mathrm{g}^{-1}$ (La) and $28 \mu \mathrm{g} \mathrm{g}^{-1}$ (Nd) to $0.3 \mu \mathrm{g} \mathrm{g}$ 1 (Lu) (Davranche et al. 2017, Kabata-Pendias 2010, McLennan 2001). As a special feature in this group, all 16 REEs exhibit ionic radii similar to $\mathrm{Ca}^{2+}$; however, under most pedological relevant conditions REEs form +3 ions (Wyttenbach et al. 1998) which strongly interact with phosphate and other negatively charged soil constituents (Cao et al. 2001; Diatloff et al. 1993; Li et al. 2014; Zhimang et al. 2000). As an exception in this group, Eu and Ce may also occur in the divalent or tetravalent state (Davranche et al. 2017). There are slight but indisputable differences in ionic radii from light REEs to heavy REEs leading to differences in their absorption and complexation behaviour in soil (fractionation). Consequently, this might also influence their movement in soil-plant systems and availability to plants. Previous studies conducted followed the generic laboratory and field approach, where synthetic REE were introduced to the cultivation area. In other approaches the cultivated plants were left to grow under natural conditions without any anthropogenic modifications (Cunha et al. 2012). There is general consensus that rhizosphere processes related to plant nutrition not only affect the availability of nutrients but also of non-essential elements such as Pb Cd (Wenzel 2009) and REEs since these elements can be mobilized through lowering of $\mathrm{pH}$ and presence of organic acids (Wiche et al. 2017a). Under field conditions Wiche et al. $(2016 a, 2016 b)$ demonstrated that mixed cultures of $P$ inefficient grasses with $P$ efficient legumes increases the uptake of REEs in the grasses which was most likely due to mobilization of REEs in the rhizosphere of lupins and movement of the elements between intermingling root systems which suggested that not the physiological mechanisms of uptake are of relevance for the accumulation levels of REEs in A. sativa and $H$. vulgare. In fact, it is generally assumed that uptake of $\mathrm{REE}^{3+}$ ions is mediated mainly, but not solely by $\mathrm{Ca}^{2+}, \mathrm{Na}^{+}, \mathrm{K}^{+}$channels (Brioschi et al. 2013; Han et al. 2005; Wiche et al. 2017b). Thus, it seems that lupins are able to attack REE-containing soil phases through the release of protons and the exudation of organic acid anions (Yan et al. 2020) which renders these elements available for the Pinefficient grasses (Wiche et al. 2016b).

In the present study we conducted a mixed culture study under field conditions where we cultivated $H$. vulgare (barley) a P inefficient cereal in presence of $11 \%$ lupins using either $L$. albus, a cluster root forming legume (white lupin) and $L$. angustifolius a non-cluster root forming lupin (blue lupin). Each of these cultivation forms was set up on two different soils with different soil $\mathrm{pH}$ and thus differences in plant-available nutrients and REEs. Additionally, on each soil, the plant stands received P-fertilizer in low and high doses to elucidate effects of P-supply and soil properties on REE accumulation in mono and mixed cultured barley plants. Moreover, in a greenhouse experiment, we characterized the root exudate composition of both lupins depending on P-supply which will give a hint on the plant's behaviour at different P-levels in the field. In this study we used mixed cultures of P-inefficient barley and P-efficient lupins (legumes) (Lambers et al. 2013; Nobile et al. 2019) as an ecologically derived approach to explore the effects of rhizosphere properties, especially rhizosphere acidification and carboxylate release on the availability of REEs to the P-inefficient cereal (Faucon et al. 2015). Knowing the dynamics of the interaction of lupins and $P$ in the rhizosphere, we hypothesise firstly, that there is an interaction between P-supply and REE accumulation in the plants and, secondly this pattern should depend on the initial availability of nutrients in the substrates determining the nutritional status of the plants and REEs mobility in the substrate. Lastly, the effects should depend on the lupin species and consequently on the amount and quality of root exudates interacting with soil phases in the intermingling rhizospheres of barley and lupins.

\section{Material And Methods}




\subsection{Field experiment}

The experiment was conducted at Bauer Umwelt Business, Hirschfeld (Saxony, Germany), in its off-site recycling and remediation centre. A basin of a total volume of $720 \mathrm{~m}^{3}$ was filled with two homogeneously sieved top soils both characterized as luvisols. One half of the basin was filled with soil from a road construction location near Freital, Germany (hereafter referred to as substrate A). The second half was filled with topsoil from a mining-affected area in the vicinity of Freiberg, Germany (hereafter referred to as substrate B). Substrate A was a silty loam with a pH $\left(\mathrm{H}_{2} \mathrm{O}\right)$ of 7.9. Substrate $B$ was a silty loam with a pH $\left(\mathrm{H}_{2} \mathrm{O}\right)$ of 6.8 (Table 1). A summary of plant-available macronutrient concentrations in the two substrates used for the experiment are shown in Table 1. The elements $\mathrm{P}, \mathrm{Mg}$ and $\mathrm{K}$ were extracted by calcium acetate lactate (CAL) and measured with ICP-MS (inductively coupled plasma-mass spectrometry). For analysis of mineral $\mathrm{N}_{1} \mathrm{NO}_{3}{ }^{-}$and $\mathrm{NH}_{4}{ }^{+}$were extracted from soil samples with deionized water and $1 \mathrm{~mol} \mathrm{~L}^{-1} \mathrm{KCl}$ respectively and photometrically determined according to Bolleter (1961) and Hartley and Asai (1963). The sum of $\mathrm{NH}_{4}{ }^{+}-\mathrm{N}^{2}$ and $\mathrm{NO}_{3}{ }^{-} \mathrm{N}$ were used to determine the bioavailable (mineral) $\mathrm{N}$ in the soil. $\mathrm{NH}_{4}{ }^{+}$-acetate $(\mathrm{pH} 5)$ was used for the extraction of exchangeable Ca which was determined through ICP-MS. Total concentrations of REEs, P, Ca, Fe and Mn of the substrate and their concentrations in six operationally defined soil fractions as a result of a sequential extraction according to (Wiche et al. 2017a) for soil samples prior to the experiment are shown in Table 2. Both substrates were characterized by similar organic matter contents (LOI), CEC and macronutrient concentrations of N, P, K and Mg (Table 1); however, Soil A displayed a significantly higher $\mathrm{pH}$ compared to Soil B indicating differences in element availability. Total concentrations of $\mathrm{P}, \mathrm{Ca}$ and Fe were significantly higher on substrate A compared to substrate B (Table 2). Also, substrate A contained higher concentrations of $\mathrm{P}, \mathrm{Ca}, \mathrm{Mn}$ and $\mathrm{Fe}$ in labile element fractions, especially exchangeable (F1), acid-soluble (F2) and organically bound elements (F3) whereas soil B was characterized by an enrichment of these elements in F4 and F5 (P, $\mathrm{Ca}, \mathrm{Fe})$ and F3 ( $\mathrm{Fe}, \mathrm{Mn})$. In contrast, there were no differences in total concentrations between soils regarding $\mathrm{Mn}$ and REEs. The REEs showed no difference in Fractions 1 and Fraction 2 but showed a substantial enrichment of LREEs in F3 of Soil B leading to a $24 \%$ higher labile LREE pool in soil B compared to soil A (Table 2).

Table 1

Characteristics of the two different substrates used in the semi-field experiment and initial nutrient concentrations at the beginning of the experiment. The values are means of 20 replicates for each soil.

\begin{tabular}{|llllllll|}
\hline Sample & $\mathbf{p H}$ & LOI & CEC $_{\text {eff }}$ & $\mathbf{N}_{\text {min }}$ & $\mathbf{P}_{\text {CAL }}$ & K & Mg \\
\hline & $\left(\mathrm{H}_{2} \mathrm{O}\right)$ & $\%$ & $\mathrm{cmol} \mathrm{kg}^{-1}$ & & & & \\
\hline Soil A & $7.9 \pm 0.4$ & $7.8 \pm 1.2$ & $15.6 \pm 2.3$ & $47 \pm 17$ & $23 \pm 9$ & $462 \pm 137$ & $243 \pm 89$ \\
\hline Soil B & $6.8 \pm 0.3$ & $6.4 \pm 1.3$ & $14.0 \pm 3.0$ & $32 \pm 9$ & $34 \pm 6$ & $284 \pm 66$ & $170 \pm 78$ \\
\hline
\end{tabular}


Table 2

Total concentration and sequential Extraction results $\left(\mu \mathrm{g} \mathrm{g}^{-1}\right)$ for the identification of the total concentrations of trace elements in the soil substrates. Given are means $\pm s d(n=10)$. Concentrations within the same element fraction between the substrates were compared by t-tests with Bonferroni adjustment. Means with different letters are statistically significantly different at $a=5 \%$.

\begin{tabular}{|c|c|c|c|c|c|c|c|c|}
\hline Fraction & Substrate & $\mathbf{P}$ & $\mathrm{Ca}$ & Mn & $\mathrm{Fe}$ & LREE & HREE & LREE/HREE \\
\hline Total & & $\begin{array}{l}1009 \pm \\
213 a\end{array}$ & $\begin{array}{l}12292 \pm \\
4595 a\end{array}$ & $\begin{array}{l}977 \pm \\
280\end{array}$ & $\begin{array}{l}31087 \pm \\
21848\end{array}$ & $\begin{array}{l}109 \pm \\
27\end{array}$ & $34 \pm 7.7$ & $3.2 \pm 0.37$ \\
\hline $\mathrm{F} 1$ & $A$ & $31 \pm 16 a$ & $\begin{array}{l}4526 \pm \\
1526 a\end{array}$ & $\begin{array}{l}77 \pm \\
25 a\end{array}$ & $3.52 \pm 1.06 a$ & $\begin{array}{l}0.3 \pm \\
0.08\end{array}$ & $\begin{array}{l}0.1 \pm \\
0.03\end{array}$ & $0.3 \pm 0.03$ \\
\hline $\mathrm{F} 2$ & & $57 \pm 12$ & $\begin{array}{l}1078 \pm \\
436 a\end{array}$ & $\begin{array}{l}194 \pm \\
35 a\end{array}$ & $222 \pm 74.3$ & $\begin{array}{l}3.7 \pm \\
0.7\end{array}$ & $1.4 \pm 0.3$ & $0.4 \pm 0.02$ \\
\hline F3 & & $\begin{array}{l}133 \pm \\
164\end{array}$ & $409 \pm 214 a$ & $\begin{array}{l}112 \pm \\
48 b\end{array}$ & $780 \pm 1033 b$ & $\begin{array}{l}7.6 \pm \\
5.0 \mathrm{~b}\end{array}$ & $\begin{array}{l}2.2 \pm \\
0.2 \mathrm{~b}\end{array}$ & $0.6 \pm 0.7 a$ \\
\hline $\mathrm{F} 4$ & & $\begin{array}{l}1121 \pm \\
400 a\end{array}$ & $75 \pm 24$ & $42 \pm 35$ & $\begin{array}{l}6508 \pm \\
2231 b\end{array}$ & $\begin{array}{l}11 \pm \\
4.5\end{array}$ & $2.5 \pm 1.2$ & $0.2 \pm 0.04$ \\
\hline F5 & & $73 \pm 23 a$ & $212 \pm 80.1$ & $29 \pm 12$ & $\begin{array}{l}4756 \pm \\
1203 b\end{array}$ & $\begin{array}{l}3.3 \pm \\
0.8\end{array}$ & $\begin{array}{l}0.8 \pm \\
0.2 \mathrm{a}\end{array}$ & $0.3 \pm 0.03$ \\
\hline Total & B & $\begin{array}{l}878 \pm \\
236 b\end{array}$ & $\begin{array}{l}5775 \pm \\
1619 b\end{array}$ & $\begin{array}{l}887 \pm \\
250\end{array}$ & $\begin{array}{l}25296 \pm \\
21848 \text { b }\end{array}$ & $\begin{array}{l}106 \pm \\
19\end{array}$ & $34 \pm 6.6$ & $3.1 \pm 0.23$ \\
\hline $\mathrm{F} 1$ & & $20 \pm 13 b$ & $\begin{array}{l}2955 \pm \\
882 b\end{array}$ & $\begin{array}{l}47 \pm \\
12 \mathrm{~b}\end{array}$ & $2.5 \pm 0.8 b$ & $\begin{array}{l}0.3 \pm \\
0.05\end{array}$ & $\begin{array}{l}0.09 \pm \\
0.01\end{array}$ & $0.3 \pm 0.03$ \\
\hline $\mathrm{F} 2$ & & $50 \pm 21$ & $513 \pm 239 b$ & $\begin{array}{l}118 \pm \\
30 \mathrm{~b}\end{array}$ & $181 \pm 85.7$ & $\begin{array}{l}3.2 \pm \\
0.7\end{array}$ & $1.0 \pm 0.2$ & $0.3 \pm 0.02$ \\
\hline F3 & & $\begin{array}{l}169 \pm \\
135\end{array}$ & $243 \pm 79.2 b$ & $\begin{array}{l}198 \pm \\
27 a\end{array}$ & $1401 \pm 930 a$ & $\begin{array}{l}9.4 \pm \\
3.2 \mathrm{a}\end{array}$ & $\begin{array}{l}2.6 \pm \\
0.8 a\end{array}$ & $0.3 \pm 0.15 b$ \\
\hline $\mathrm{F} 4$ & & $\begin{array}{l}1496 \pm \\
412 b\end{array}$ & $69 \pm 20$ & $38 \pm 18$ & $\begin{array}{l}8049 \pm \\
1777 a\end{array}$ & $\begin{array}{l}11 \pm \\
4.0\end{array}$ & $2.3 \pm 0.8$ & $0.1 \pm 0.01$ \\
\hline F5 & & $\begin{array}{l}110 \pm \\
21 b\end{array}$ & $237 \pm 84.7$ & $\begin{array}{l}31 \pm \\
5.4\end{array}$ & $6396 \pm 557 a$ & $\begin{array}{l}3.0 \pm \\
0.6\end{array}$ & $\begin{array}{l}0.7 \pm \\
0.1 \mathrm{~b}\end{array}$ & $0.3 \pm 0.02$ \\
\hline
\end{tabular}

\subsection{Plant cultivation}

White lupin (Lupinus albus L., cv. Foedora), blue lupin (Lupinus angustifolius L., cv. Sonate) and barley (Hordeum vulgare L. CV. Modena) were grown within field conditions in both a monoculture and a mixed culture system on 80 plots with an area of $4 \mathrm{~m}^{2}$ each, to assess the migration of REE in soil influenced by intercropping. To avoid interactions between adjacent plots (e.g., root interactions, water discharge, nutrients, REE and trace metals), a $0.5 \mathrm{~m}$ buffer zone was maintained surrounding each plot without vegetation. In a symmetrically modified replacement series configuration, all of the plants were planted in rows (leaving $20 \mathrm{~cm}$ between rows). In that sense a total density of $400 \mathrm{seeds} / \mathrm{m}^{2}$ were used when seeding, for the monoculture (referred to as LO from henceforth), and also for the mixed culture plots. Mixed barley cultures were obtained from the monocultures by replacement of $11 \%$ barley plants with the equivalent proportion of individuals of white lupin and blue lupin (hereinafter referred to as Lal and Lan plots) and thus plant densities were equivalent in both barley monocultures and mixed cultures. Additionally, plants in mixed crops were cultivated in various patterns with regard to agricultural practices, on rows determining the degree of plant interactions. 
Eight days after seed germination and plant development had taken place, the first dose of fertilizer was given to all plants. On each substrate plots with barley monoculture and mixed cultures with white and blue lupin (Lal and Lan) were dosed with $10 \mathrm{~g}$ of $\mathrm{N} \mathrm{m}^{-2}$ as $\mathrm{NH}_{4} \mathrm{NO}_{3}, 11.6 \mathrm{~g} \mathrm{~K} \mathrm{~m}^{-2}$ as $\mathrm{KNO}_{3}, 3 \mathrm{~g}$ of $\mathrm{P} \mathrm{m}^{-2}$ as $\mathrm{KH}_{2} \mathrm{PO}_{4}, 1.5 \mathrm{~g} \mathrm{Mg} \mathrm{m}^{-2}$ as $\mathrm{MgSO}_{4}$ representing the fully fertilized reference plants (NPK). Accordingly, on each substrate plots of barley monoculture (L0) and mixed cultures with blue lupin (Lan) received a similar fertilizer composition regarding $\mathrm{N}, \mathrm{K}$ and $\mathrm{Mg}$ but with one third of $\mathrm{P}\left(1 \mathrm{~g}\right.$ of $\mathrm{P} \mathrm{m}^{-2}$ as $\left.\mathrm{KH}_{2} \mathrm{PO}_{4}\right)$ representing the low dosed variant (NK). To ensure consistency in the provision of nutrients throughout the entire experiment and to avert $\mathrm{N}$ deficiency, (e.g., by leaching nitrate), the abovementioned fertilizer was applied in two separate doses at the beginning of the experiment and a second time four weeks later.

Overall, this experimental design allowed a comparison between responses to different culture types on P-supply, a comparison of lupins under fully fertilized conditions and the influence of the growing substrate. Each of the different treatments, including culture forms and fertilizer treatment were fivefold replicated on each of the two substrates and within each substrate the treatments were setup in a fully randomized design. After eight weeks of plant growth shoots of barley in monocultures and mixed cultures were cut $3 \mathrm{~cm}$ above the soil surface. Only the shoots of the inner square meter of each plot were further processed for chemical analysis.

\subsection{Quantification of carboxylate release}

A separate greenhouse experiment was designed for the determination of root exudates in both $L$. albus and $L$. angustifolius depending on P-supply. Seeds of L. albus cv Feodora and L. angustifolius cv. Sonate were surface sterilized by washing the seeds with $0.5 \%$ sodium hypochlorite $(\mathrm{NaOCl})$ for three minutes followed by carefully rinsing with deionized water and allowed to germinate in petri dishes in a climate chamber at $20^{\circ} \mathrm{C}$. After germination the seedlings of each plant species (one seedling per pot) were planted in 10 plastic pots ( $2 \mathrm{~L}$ total volume) filled with acid $\left(\mathrm{HNO}_{3}\right)$ washed quartz sand. The pots were incubated in a greenhouse for six weeks with a $15 \mathrm{~h}$ photoperiod, $18-30^{\circ} \mathrm{C}$, relative humidity $65 \%$, and average photosynthetically active photon flux density of $630 \mu \mathrm{mol} \mathrm{m} \mathrm{m}^{-2} \mathrm{~s}^{-1}$. During a time period of four weeks, all plants received weekly $200 \mathrm{~mL}$ of nutrient solutions that contained $2 \mathrm{mmol} \mathrm{L}^{-1} \mathrm{KNO}_{3}, 1.5 \mathrm{mmol} \mathrm{L}^{-1} \mathrm{NH}_{4} \mathrm{NO}_{3}, 1 \mathrm{mmol} \mathrm{L}^{-1}$ $\mathrm{Ca}\left(\mathrm{NO}_{3}\right)_{2}, 1 \mathrm{mmol} \mathrm{L}-1 \mathrm{CaCl}_{2}, 1 \mathrm{mmol} \mathrm{L} \mathrm{MgSO}_{4}, 2.5 \mathrm{mmol} \mathrm{L}^{-1} \mathrm{H}_{3} \mathrm{BO}_{3}, 0.5 \mathrm{mmol} \mathrm{L}^{-1} \mathrm{MnCl}_{2}, 0.02 \mathrm{mmol} \mathrm{L}^{-1} \mathrm{CuSO}_{4}, 0.03$ $\mathrm{mmol} \mathrm{L}^{-1} \mathrm{ZnSO}_{4}, 0.005 \mathrm{mmol} \mathrm{L}^{-1}\left(\mathrm{NH}_{4}\right)_{6}\left(\mathrm{Mo}_{7} \mathrm{O}_{24}\right)$, and $0.7 \mathrm{mmol} \mathrm{L}^{-1}$ ethylenediaminetetraacetic-iron (Fe-EDTA). Additionally, for each species, one half of the plants received $200 \mu \mathrm{mol} \mathrm{L}^{-1} \mathrm{~K}_{2} \mathrm{HPO}_{4}$ together with the other nutrients ( $\mathrm{P}+$ ) while the other plants received $20 \mu \mathrm{mol} \mathrm{L}^{-1} \mathrm{P}$ (P-references). After a cultivation period of four weeks, the mature plants were carefully removed from the sand by washing with tap water and transferred into glass beakers containing $300 \mathrm{~mL}$ of a $2.5 \mu \mathrm{mol} \mathrm{L}{ }^{-1} \mathrm{CaCl}_{2}$ solution where they were let to stay for two hours under a growth lamp and allowed to release carboxylates into the collection solutions. Immediately after the collection the resulting solutions were stabilized with 1 $\mathrm{mL} \mathrm{L}^{-1}$ Micropur to prevent microbial decomposition of carboxylates according to Oburger et al. (2013) and analysed by means of ion chromatography. Thereafter, the shoots and roots were separated, weight and dried for $24 \mathrm{~h}$ at $60^{\circ} \mathrm{C}$.

\subsection{Analysis of trace element concentrations and carboxylates}

The harvested biomass of field grown plants was separated in leaves and stems and dried at $60^{\circ} \mathrm{C}$ in an oven for $24 \mathrm{~h}$. The dried biomass was ground to fine powder and stored in centrifuge tubes. Thereafter microwave digestion (Ethos plus 2 , MLS) was carried out with $0.1 \mathrm{~g}$ of subsample taken from the ground biomass measured in duplicates. Samples were mixed with $1.6 \mathrm{~mL}$ nitric acid ( $65 \%$ supra) and $0.6 \mathrm{~mL}$ hydrofluoric acid ( $4.9 \%$ supra ${ }^{-}$) and heated to $220^{\circ} \mathrm{C}$ in the microwave according to Krachler et al. (2002). Concentrations of P, Fe, Mn, Ca, Mg, and REEs (Y, La, Ce, Pr, Nd, Sm, Eu, Gd, Tb, Dy, Ho, Er, Tm, Yb and Lu) from the diluted digestion solutions and soil solutions were determined by ICP-MS (XSeries 2, Thermo scientific) using $10 \mu \mathrm{g} \mathrm{L}^{-1}$ rhodium and rhenium as internal standards. 
Concentrations of acetate, malonate, fumarate, glutarate, malate and citrate in the collection solutions were determined by ion chromatography equipped with suppressed conductivity detection (ICS-5000, $4 \mathrm{~mm}$ system, Thermo Scientific). Inorganic and organic acid anions were separated at $30^{\circ} \mathrm{C}$ on an IonPac ${ }^{\circledR}$ AS11-HC column (Thermo Scientific) using gradient elution with sodium hydroxide as eluent and a flow rate of $1.0 \mathrm{~mL} / \mathrm{min}$. The measuring program started with an

eight-minute isocratic phase and a sodium hydroxide concentration of $1 \mathrm{mmol} \mathrm{L}^{-1}$, followed by the gradient analysis with a continuously increasing sodium hydroxide concentration up to $40 \mathrm{mmol} \mathrm{L}^{-1}$ over a period of $35 \mathrm{~min}$. Finally, the column was flushed for three minutes with $50 \mathrm{mmol} \mathrm{L}^{-1}$ sodium hydroxide and equilibrated for ten minutes with $1 \mathrm{mmol} \mathrm{L}^{-1}$ sodium hydroxide, so in total the analysis took $56 \mathrm{~min}$.

\subsection{Data processing and statistical analysis}

Concentrations of light rare earth elements (LREEs) and heavy rare earth elements (HREEs) in the plant and soil samples were calculated according to Tyler (2004) as sums of La, Ce, Pr, Nd, Pm, Sm, Eu (LREEs) and Gd, Tb, Y, Ho, Er, Yb, Tm, Lu (HREEs). Significant differences among means of element concentrations in soil fractions, carboxylate concentrations of $\mathrm{P}+$ and $\mathrm{P}$ - treated plants, $\mathrm{P}$ concentrations in lupines cultivated with different $\mathrm{P}$ supply were compared by t-test with Bonferroni adjustment of p-values using IBM SPSS Statistics 25. Additionally, concentrations and contents in different plant parts of the same plants were compared by a t-test for non-independent samples at $a=5 \%$. Means of plant yield, element concentrations and contents (calculated as concentrations $\times$ biomass) in different plant parts resulting from different culture forms (monocultures and mixed cultures with different lupins) as well as factors contributing to altered plant accumulation was evaluated by multifactor multivariate analysis of variance (MANOVA) using a type III model. In case of significant effects indicated by a significant Wilks-Lambda at $p<0.05$ Duncans' post-hoc test was used. Prior to the analysis the data was checked for homogeneity of variances using Levenes-test. In case that the assumption of homogeneity was violated, the data was log-transformed. If the assumption was still violated significant differences of means were identified by using single comparisons of groups of means using Welchs's ANOVA at $a=5 \%$.

\section{Results}

\subsection{Root exudate patterns in $L$. albus and $L$. angustifolius affected by P-supply}

Compared to L. angustifolius, L. albus produced higher shoot biomass ( $P+203 \%, P-137 \%)$, and root biomass ( $+400 \%$, P-233\%), irrespective of P-supply (Table 3). P-supply did not influence root and shoot dry mass in L. angustifolius as well as root dry mass in L. albus. However, the shoot dry mass of $L$. albus responded to differences in P-supply showing a reduction by $35 \%$ when plants were supplied with low $\mathrm{P}$ doses. From the carboxylates measured, only citrate and malate were detectable in all collection solutions (Table 3), while fumarate was only occasionally present. All other carboxylate signals (acetate, lactate, glutarate, malonate) were below their respective detection limits. Under conditions of low Psupply L. albus strongly responded by $271 \%$ increased rates of citrate release per unit root dry mass and showed $71 \%$ increased release of citrate per plant (Table 3). In this study P- supply did not alter release of malate by L. albus. In contrast, in L. angustifolius, P-deficiency did not increase release of carboxylates. Instead, in L. angustifolius in adequately P-supplied plants exudation rates of citrate and malate per unit root dry mass were $224 \%$ and $243 \%$, respectively, higher than in P-deficient plants. Overall, in L. angustifolius this resulted in a 180\% higher release of citrate and $650 \%$ higher release of malate in P-supplied plants. A comparison of exudation rates and amounts of carboxylate release per unit root dry mass between two lupin species revealed that there was no difference in the exudation rates under low P-supply. However, when the plants received high P-doses with the treatment solutions, exudation rates of citrate and malate in L. angustifolius per unit root dry mass were $1100 \%$ (citrate) and $140 \%$ (malate) higher than in $L$. albus $(\mathrm{p}<0.05)$. Considering the amounts of carboxylates released per plant individual $\left(\mu \mathrm{M} \mathrm{h}^{-1}\right)$ under P-deficiency $L$. 
albus released $140 \%$ and $900 \%$ more citrate and malate, respectively. In contrast, when P-supply was high, $L$. angustifolius released $100 \%$ more citrate while release of malate was similar.

Table 3

Growth parameters and root carboxylates collected from L. albus and L. angustifolius that were semi-hydroponically cultivated under P-deficient conditions (20 $\mu \mathrm{M}$ P: P-) or supply of $200 \mu \mathrm{M} \mathrm{P}(\mathrm{P}+)$. The values are means $\pm s d(n=4)$. Significant differences among parameters within a species and between species and within a specific P-treatment were identified by a t-test with Bonferroni adjustment.

\begin{tabular}{|c|c|c|c|c|c|c|c|c|c|}
\hline \multirow[t]{2}{*}{ Species } & \multirow[b]{2}{*}{$\begin{array}{l}\text { P- } \\
\text { supply }\end{array}$} & \multicolumn{2}{|c|}{ Growth parameter } & \multicolumn{2}{|c|}{ Release per plant } & \multirow[b]{2}{*}{ fumarate } & \multicolumn{3}{|c|}{ Release per dry weight } \\
\hline & & Root dw & Shoot dw & citrate & malate & & Citrate & malate & fumarate \\
\hline & & $\mathrm{g}$ & & $\mu \mathrm{M} \mathrm{h}^{-1}$ & & & $\mu \mathrm{mol}(\mathrm{g}$ & $w h)^{-1}$ & \\
\hline \multirow[t]{3}{*}{ Lal } & $\mathrm{P}+$ & $0.8 \pm 0.2$ & $2.3 \pm 0.4$ & $\begin{array}{l}0.7 \pm \\
0.1\end{array}$ & $0.6 \pm 0.4$ & $\begin{array}{l}0.02 \pm \\
0.01\end{array}$ & $\begin{array}{l}0.8 \pm \\
0.1\end{array}$ & $\begin{array}{l}1.0 \pm \\
0.3\end{array}$ & $\begin{array}{l}0.08 \pm \\
0.07\end{array}$ \\
\hline & P- & $0.6 \pm 0.3$ & $1.5 \pm 0.7$ & $\begin{array}{l}1.2 \pm \\
0.1\end{array}$ & $0.8 \pm 0.2$ & $<0.01$ & $\begin{array}{l}3.0 \pm \\
1.4\end{array}$ & $\begin{array}{l}1.1 \pm \\
0.6\end{array}$ & $<0.02$ \\
\hline & p-value & 0.43 & 0.08 & $<0.01$ & 0.24 & 0.34 & 0.03 & 0.91 & NA \\
\hline \multirow[t]{3}{*}{ Lan } & $\mathrm{P}+$ & $\begin{array}{l}0.16 \pm \\
0.13\end{array}$ & $\begin{array}{l}0.76 \pm \\
0.45\end{array}$ & $\begin{array}{l}1.4 \pm \\
0.5\end{array}$ & $0.6 \pm 0.3$ & $<0.01$ & $\begin{array}{l}9.4 \pm \\
4.1\end{array}$ & $\begin{array}{l}2.4 \pm \\
0.6\end{array}$ & $<0.06$ \\
\hline & P- & $\begin{array}{l}0.18 \pm \\
0.08\end{array}$ & $\begin{array}{l}0.59 \pm \\
0.21\end{array}$ & $\begin{array}{l}0.5 \pm \\
0.3\end{array}$ & $\begin{array}{l}0.08 \pm \\
0.01\end{array}$ & $<0.01$ & $\begin{array}{l}2.9 \pm \\
0.4\end{array}$ & $\begin{array}{l}0.7 \pm \\
0.3\end{array}$ & $<0.06$ \\
\hline & p-value & 0.88 & 0.82 & 0.06 & 0.04 & NA & 0.04 & 0.01 & NA \\
\hline \multirow[t]{2}{*}{ p-value } & $\mathrm{P}+$ & $<0.01$ & $<0.01$ & 0.04 & 0.83 & NA & 0.02 & 0.01 & NA \\
\hline & P- & 0.22 & 0.07 & 0.04 & 0.01 & NA & 0.95 & 0.43 & NA \\
\hline
\end{tabular}

\subsection{Plant growth and nutrient concentrations in mono- and mixed cultured barley plants}

In all experimental units, biomass of $H$. vulgare shoots consisted mostly of stem biomass which on average yielded $122 \%$ more biomass per unit area than leaves (Table 5). Substrate properties, culture form (mixed culture with different mixing ratios of $L$. albus or L. angustifolius) and P-fertilization did not influence biomass yields of stems of $H$. vulgare (Table 4 and 5) and there were no differences in leaf biomasses between substrates. Also, intercropping and P-addition did not influence leaf biomass on substrate B, neither in plant stands with L. albus, nor with L. angustifolius. However, on substrate A, mixed culture cultivation with L. angustifolius slightly increased $(p=0.09)$ leaf biomass of barley when barley was cultivated at low P-application level (NK) (Table 4) showing a 126\% higher leaf biomass compared to the monocultures. This increase resulting from intercropping was not observable in NPK treated plants on substrate A and thus leaf biomasses in mixed cultures grown under NK addition were by $195 \%$ higher $(p=0.06)$ compared to barley plants grown in NPK treated mixed cultures.

A comparison of concentrations in leaves and stems, respectively, and considering data from both substrates and all culture forms and fertilizer treatments revealed that concentrations of all investigated elements were consistently higher in leaves compared to the stems, except for $P$ on substrate $B$. On substrate $A$, leaf concentrations were $28 \%(P), 171 \%$ (Ca), 196\% (Mn) and 316\% (Fe) higher than in stems. On substrate B leaf concentrations were 201\% (Ca), 213\% (Mn) and $405 \%$ (Fe) higher than in stems. 
The addition of high doses of P-fertilizer did not affect the concentrations of $\mathrm{Ca}, \mathrm{Fe}, \mathrm{Mn}$ and $\mathrm{P}$ in leaves and stems, respectively, irrespective of the growth substrate. The growth substrate strongly affected concentrations of $\mathrm{Ca}, \mathrm{Mn}$ and $\mathrm{Fe}$ $(p<0.01)$ and slightly affected $P$ concentrations $(p<0.1)$ in leaves, while in stems the growth substrate highly affected $P$, $\mathrm{Ca}$ and $\mathrm{Mn}$ concentrations with no significant effects on Fe. Specifically, considering all data from mixed culture types ( $L$. albus and L. angustifolius) and P-fertilizer treatments, leaf concentrations on substrate B were 13\% (P), 45\% (Ca), 213\% $(\mathrm{Mn})$ and $44 \%(\mathrm{Fe})$ higher than on Substrate A. In the same manner, stem concentrations of plants cultivated on substrate B were 43\% (P), 31\% (Ca) and 220\% (Mn) higher than on substrate A. Moreover, besides major effects of the substrate, multifactor MANOVA revealed significant effects of intercropping (culture form) on Mn in leaves $(p<0.001)$ and marginally significant effects on $\mathrm{Ca}(\mathrm{p}=0.08)$, while in the tillers concentrations of $\mathrm{P}$ and Fe exhibited significant substrate-culture interactions, indicating that the effect of culture form depends on the growth substrate. More specifically in both substrates, concentrations of $\mathrm{Ca}$ increased by $33 \%$ and $26 \%$ in leaves of $\mathrm{H}$. vulgare when the plants were cultivated in mixed cultures with $L$. angustifolius compared to the monocultures (LO), whereas there was no significant effect from $L$. albus. Additionally, leaf $\mathrm{Mn}$ concentrations increased highly significantly $(p<0.01)$ as an effect of mixed culture cropping with $L$. albus by $100 \%$ on substrate $A$ and by $153 \%$ on substrate $B$, while the presence of $L$. angustifolius did not influence $\mathrm{Mn}$ in mixed cultured barley. In the stems, mixed cultures with L. angustifolius increased the P concentration significantly by $64 \%(p=0.06)$ compared to the monocultures but this effect was only visible on substrate A. The presence of $L$. angustifolius significantly increased Fe concentrations in tillers of barley by $57 \%$ but this effect was only observable on substrate B. Compared to the leaves there was no effect of the mixed cultures on $\mathrm{Ca}$ and Mn in tillers of mixed cultured barley, and. compared to L. albus, the presence of $L$. angustifolius led to more substantial changes in mineral element composition of $H$. vulgare, except for $\mathrm{Mn}$ which was highly affected by $L$. albus.

Table 4

Multifactor multivariate ANOVA based on leaf and stem concentrations of barley plants exploring for effects of the growth substrate, fertilizer ( $\mathrm{P}+$; $\mathrm{P}-$-)-addition and culture form (mono and mixed cultures). (*) $p<0.1 ; * p<0.05 ; * * p<0.01$; NS not significant.

\begin{tabular}{|c|c|c|c|c|c|c|c|c|c|}
\hline Plant tissue & Source of variation & Yield & $\mathbf{P}$ & $\mathrm{Ca}$ & Mn & $\mathrm{Fe}$ & LREE & HREE & $\mathrm{L} / \mathrm{H}$ \\
\hline \multirow[t]{5}{*}{ Leaves } & Substrate & NS & $(*)$ & $\star \star \star$ & $\star * \star$ & $\star \star \star$ & ** & * & NS \\
\hline & Fertilizer & $(*)$ & NS & NS & NS & NS & NS & NS & NS \\
\hline & Culture & * & NS & $(*)$ & $\star \star$ & NS & NS & NS & NS \\
\hline & Substrate*Culture & NS & NS & NS & NS & NS & NS & NS & NS \\
\hline & Fertilizer*Culture & NS & NS & NS & NS & NS & * & * & $(*)$ \\
\hline \multirow[t]{5}{*}{ Stems } & Substrate & NS & ** & * & $\star *$ & NS & NS & NS & NS \\
\hline & Fertilizer & NS & NA & NA & NS & NS & NS & NS & NS \\
\hline & Culture & NS & NS & NS & NS & NS & $(*)$ & NS & * \\
\hline & Substrate*Culture & NS & * & NS & NS & * & ** & * & NS \\
\hline & Fertilizer*Culture & NS & NS & NS & NS & NS & NS & NS & NS \\
\hline
\end{tabular}


Table 5

Yield of leaves and stems and concentrations of phosphorus (P), calcium (Ca), manganese (Mn) and iron (Fe) in the plant parts of $H$. vulgare depending on substrate (slightly alkaline substrate A and slightly acidic substrate B), P addition (low dose, $\mathrm{P}$ - and high dose, $\mathrm{P}+$ ) and culture form (monoculture: LO, mixed culture with $11 \% \mathrm{~L}$. albus, Lal, and mixed culture with $11 \%$ L. angustifolius, Lan). Means $\pm \mathrm{sd}(\mathrm{n}=5)$. Significant differences in yields and concentrations within a plant part and substrate were identified by MANOVA followed by Duncan's' post-hoc test. Small letters show differences between means of mono and mixed cultured barley within a specific substrate and P-treatment. Capital letters denote differences of concentrations in barley plants of a specific treatment between P-treatments within a substrate. Capital letters in italics show differences of concentrations in barley plants between substrates at $a=0.05$.

\begin{tabular}{|c|c|c|c|c|c|c|c|c|c|c|c|c|}
\hline \multicolumn{3}{|c|}{ Culture form } & \multicolumn{5}{|l|}{ Leaves } & \multicolumn{5}{|c|}{ Stems } \\
\hline \multirow[t]{2}{*}{ Substrate } & Fertilizer & Culture & yield & $\mathrm{P}$ & $\mathrm{Ca}$ & $\mathrm{Mn}$ & $\mathrm{Fe}$ & yield & $\mathrm{P}$ & $\mathrm{Ca}$ & $\mathrm{Mn}$ & $\mathrm{Fe}$ \\
\hline & & & $\mathrm{g} \mathrm{m}^{-2}$ & \multicolumn{2}{|c|}{$\mathrm{mg} \mathrm{g}^{-1}$} & \multicolumn{2}{|l|}{$\mu g^{-1}$} & $\begin{array}{l}\mathrm{g} \\
\mathrm{m}^{-2}\end{array}$ & \multicolumn{2}{|l|}{$\mathrm{mg} \mathrm{g}^{-1}$} & \multicolumn{2}{|c|}{$\mu g^{-1}$} \\
\hline \multirow[t]{5}{*}{$A$} & NK & LO & $\begin{array}{l}85 \pm \\
13 b\end{array}$ & $\begin{array}{l}1.9 \\
\pm \\
0.4\end{array}$ & $\begin{array}{l}5.6 \pm \\
1.9\end{array}$ & $\begin{array}{l}13 \pm \\
3 B\end{array}$ & $\begin{array}{l}117 \\
\pm \\
36 B\end{array}$ & $\begin{array}{l}155 \\
\pm 46\end{array}$ & $\begin{array}{l}1.4 \pm \\
0.5(\mathrm{~b}) B\end{array}$ & $\begin{array}{l}2.2 \\
\pm \\
0.5\end{array}$ & $\begin{array}{l}4.5 \\
\pm \\
0.9 B\end{array}$ & $\begin{array}{l}25 \\
\pm \\
9 B\end{array}$ \\
\hline & & Lan & $\begin{array}{l}192 \pm \\
116 a(A)\end{array}$ & $\begin{array}{l}2.3 \\
\pm \\
0.4\end{array}$ & $\begin{array}{l}6.4 \pm \\
1.3\end{array}$ & $\begin{array}{l}16 \pm \\
3 B\end{array}$ & $\begin{array}{l}146 \\
\pm \\
41 B\end{array}$ & $\begin{array}{l}317 \\
\pm \\
186\end{array}$ & $\begin{array}{l}2.3 \pm \\
0.4(a)\end{array}$ & $\begin{array}{l}2.2 \\
\pm \\
0.2\end{array}$ & $\begin{array}{l}5.7 \\
\pm \\
0.7 B\end{array}$ & $\begin{array}{l}28 \\
\pm 5\end{array}$ \\
\hline & NPK & LO & $65 \pm 12$ & $\begin{array}{l}2.0 \\
\pm \\
0.3\end{array}$ & $\begin{array}{l}5.2 \pm \\
0.9(a)\end{array}$ & $\begin{array}{l}12 \pm \\
2 \mathrm{a} A\end{array}$ & $\begin{array}{l}111 \\
\pm \\
15 A\end{array}$ & $\begin{array}{l}192 \\
\pm 41\end{array}$ & $\begin{array}{l}1.3 \pm \\
0.6 B\end{array}$ & $\begin{array}{l}2.1 \\
\pm \\
0.4\end{array}$ & $\begin{array}{l}5.9 \\
\pm \\
3.2 B\end{array}$ & $\begin{array}{l}29 \\
\pm 7\end{array}$ \\
\hline & & Lan & $\begin{array}{l}65 \pm \\
17(\mathrm{~B})\end{array}$ & $\begin{array}{l}2.0 \\
\pm \\
0.4\end{array}$ & $\begin{array}{l}6.9 \pm \\
1.3(\mathrm{~b}) A\end{array}$ & $\begin{array}{l}14 \pm \\
2 \mathrm{a} A\end{array}$ & $\begin{array}{l}152 \\
\pm \\
55\end{array}$ & $\begin{array}{l}153 \\
\pm 26\end{array}$ & $\begin{array}{l}1.9 \pm \\
0.5\end{array}$ & $\begin{array}{l}2.3 \\
\pm \\
0.6\end{array}$ & $\begin{array}{l}5.7 \\
\pm \\
0.8 B\end{array}$ & $\begin{array}{l}34 \\
\pm 6\end{array}$ \\
\hline & & Lal & $53 \pm 12$ & $\begin{array}{l}2.1 \\
\pm \\
0.4\end{array}$ & $\begin{array}{l}5.3 \pm \\
0.9(a)\end{array}$ & $\begin{array}{l}24 \pm \\
7 b\end{array}$ & $\begin{array}{l}140 \\
\pm \\
32\end{array}$ & $\begin{array}{l}157 \\
\pm 66\end{array}$ & $\begin{array}{l}1.2 \pm \\
0.7\end{array}$ & $\begin{array}{l}2.1 \\
\pm \\
0.4\end{array}$ & $\begin{array}{l}5.6 \\
\pm \\
1.2\end{array}$ & $\begin{array}{l}41 \\
\pm \\
10\end{array}$ \\
\hline \multirow[t]{5}{*}{ B } & NK & LO & $92 \pm 41$ & $\begin{array}{l}2.6 \\
\pm \\
0.8\end{array}$ & $\begin{array}{l}6.8 \pm \\
1.8(b)\end{array}$ & $\begin{array}{l}41 \pm \\
4 A\end{array}$ & $\begin{array}{l}204 \\
\pm \\
66 \mathrm{~A}\end{array}$ & $\begin{array}{l}158 \\
\pm 41\end{array}$ & $\begin{array}{l}2.6 \pm \\
0.4 A\end{array}$ & $\begin{array}{l}2.4 \\
\pm \\
0.5\end{array}$ & $\begin{array}{l}19 \pm \\
4 A\end{array}$ & $\begin{array}{l}48 \\
\pm \\
8 \mathrm{~A} A\end{array}$ \\
\hline & & Lan & $95 \pm 40$ & $\begin{array}{l}2.0 \\
\pm \\
0.2\end{array}$ & $\begin{array}{l}8.6 \pm \\
1.2(a)\end{array}$ & $\begin{array}{l}35 \pm \\
13 A\end{array}$ & $\begin{array}{l}202 \\
\pm \\
17 A\end{array}$ & $\begin{array}{l}123 \\
\pm 23\end{array}$ & $\begin{array}{l}2.7 \pm \\
0.5\end{array}$ & $\begin{array}{l}2.8 \\
\pm \\
0.8\end{array}$ & $\begin{array}{l}12 \pm \\
6 A\end{array}$ & $\begin{array}{l}36 \\
\pm 7\end{array}$ \\
\hline & NPK & LO & $61 \pm 17$ & $\begin{array}{l}2.0 \\
\pm \\
0.6\end{array}$ & $\begin{array}{l}8.9 \pm \\
4.8\end{array}$ & $\begin{array}{l}40 \pm \\
23 a B\end{array}$ & $\begin{array}{l}177 \\
\pm \\
45 B\end{array}$ & $\begin{array}{l}164 \\
\pm 47\end{array}$ & $\begin{array}{l}2.1 \pm \\
0.6 A\end{array}$ & $\begin{array}{l}2.7 \\
\pm \\
1.2\end{array}$ & $\begin{array}{l}15 \pm \\
12 A\end{array}$ & $\begin{array}{l}28 \\
\pm \\
6 \mathrm{aB}\end{array}$ \\
\hline & & Lan & $77 \pm 32$ & $\begin{array}{l}2.2 \\
\pm \\
0.5\end{array}$ & $\begin{array}{l}9.2 \pm \\
1.5 B\end{array}$ & $\begin{array}{l}47 \pm \\
13 \mathrm{a} B\end{array}$ & $\begin{array}{l}196 \\
\pm \\
61\end{array}$ & $\begin{array}{l}127 \\
\pm 65\end{array}$ & $\begin{array}{l}2.0 \pm \\
0.4\end{array}$ & $\begin{array}{l}2.9 \\
\pm \\
0.4\end{array}$ & $\begin{array}{l}17 \pm \\
9 A\end{array}$ & $\begin{array}{l}44 \\
\pm \\
11 \mathrm{~b}\end{array}$ \\
\hline & & Lal & $50 \pm 14$ & $\begin{array}{l}2.4 \\
\pm \\
0.5\end{array}$ & $\begin{array}{l}10.4 \pm \\
3.5\end{array}$ & $\begin{array}{l}101 \\
\pm \\
49 \mathrm{~b}\end{array}$ & $\begin{array}{l}184 \\
\pm \\
23\end{array}$ & $\begin{array}{l}135 \\
\pm 34\end{array}$ & $\begin{array}{l}1.9 \pm \\
0.3\end{array}$ & $\begin{array}{l}3.6 \\
\pm \\
0.8\end{array}$ & $\begin{array}{l}16 \pm \\
6\end{array}$ & $\begin{array}{l}31 \\
\pm \\
6 a\end{array}$ \\
\hline
\end{tabular}


Table 6

Concentrations $\left(\mu \mathrm{g} \mathrm{g}^{-1}\right.$ ) of light rare earth elements (LREEs) and heavy rare earth elements (HREEs) and their ratio (LREEs relative to HREEs) in the plant parts depending on substrate (slightly alkaline substrate A and slightly acidic substrate B),

$\mathrm{P}$ addition (low dose P- and high dose P+) and culture form (monoculture: L0, mixed culture with $11 \%$ L. albus: Lal and mixed culture with $11 \%$ L. angustifolius: Lan). Means $\pm s d(n=5)$. Significant differences in yields and concentrations within a plant part and substrate were identified by MANOVA followed by Duncan's' post-hoc test. Small letters show differences between means of mono and mixed cultured barley within a specific substrate and P-treatment. Capital letters denote differences of concentrations in barley plants of a specific treatment between P-treatments within a substrate. Capital letters in italics show differences of concentrations in barley plants between substrates at $a=5 \%$.

\begin{tabular}{|c|c|c|c|c|c|c|c|c|}
\hline & & & Leaves & & & Stems & & \\
\hline Substrate & Fertilizer & Culture & LREE & HREE & $\mathrm{L} / \mathrm{H}$ & LREE & HREE & $\mathrm{L} / \mathrm{H}$ \\
\hline \multirow[t]{5}{*}{$A$} & \multirow[t]{2}{*}{ NK } & LO & $\begin{array}{l}0.44 \pm \\
0.20 A B\end{array}$ & $\begin{array}{l}0.12 \pm \\
0.09\end{array}$ & $\begin{array}{l}4.4 \pm \\
1.5 a\end{array}$ & $\begin{array}{l}0.08 \pm \\
0.04(\mathrm{~A})\end{array}$ & $0.04 \pm 0.02(\mathrm{~A})$ & $\begin{array}{l}2.5 \pm \\
0.7\end{array}$ \\
\hline & & Lan & $0.41 \pm 0.19$ & $\begin{array}{l}0.24 \pm \\
0.21\end{array}$ & $\begin{array}{l}2.7 \pm \\
1.3 \mathrm{~b}\end{array}$ & $0.04 \pm 0.03(B)$ & $0.15 \pm 0.13$ & $\begin{array}{l}1.4 \pm \\
0.9\end{array}$ \\
\hline & \multirow[t]{3}{*}{ NPK } & LO & $\begin{array}{l}0.23 \pm \\
0.06 \mathrm{bB} B\end{array}$ & $\begin{array}{l}0.07 \pm \\
0.02 \mathrm{~b} B\end{array}$ & $\begin{array}{l}3.7 \pm \\
0.6\end{array}$ & $\begin{array}{l}0.04 \pm \\
0.02 \mathrm{~b}(\mathrm{~B}) B\end{array}$ & $\begin{array}{l}0.02 \pm 0.01(\mathrm{~b}) \\
(\mathrm{B}) B\end{array}$ & $\begin{array}{l}3.2 \pm \\
0.2 \mathrm{a}\end{array}$ \\
\hline & & Lan & $\begin{array}{l}0.49 \pm \\
0.21 \mathrm{a}\end{array}$ & $\begin{array}{l}0.12 \pm \\
0.05 a B\end{array}$ & $\begin{array}{l}3.8 \pm \\
0.7\end{array}$ & $\begin{array}{l}0.13 \pm \\
0.06 \mathrm{a}(\mathrm{A}) A\end{array}$ & $\begin{array}{l}0.06 \pm \\
0.03(\mathrm{a}) A\end{array}$ & $\begin{array}{l}2.2 \pm \\
0.3 \mathrm{~b} B\end{array}$ \\
\hline & & Lal & $\begin{array}{l}0.37 \pm \\
0.15 \mathrm{ab}\end{array}$ & $\begin{array}{l}0.10 \pm \\
0.06 a b\end{array}$ & $\begin{array}{l}4.0 \pm \\
0.9\end{array}$ & $\begin{array}{l}0.07 \pm \\
0.04 a b\end{array}$ & $\begin{array}{l}0.03 \pm \\
0.02(a b)\end{array}$ & $\begin{array}{l}3.2 \pm \\
0.7 \mathrm{a}\end{array}$ \\
\hline \multirow[t]{5}{*}{ B } & \multirow[t]{2}{*}{ NK } & LO & $0.77 \pm 0.28 \mathrm{~A}$ & $\begin{array}{l}0.18 \pm \\
0.07\end{array}$ & $\begin{array}{l}4.2 \pm \\
0.5 \mathrm{~A}\end{array}$ & $0.09 \pm 0.04$ & $0.04 \pm 0.03$ & $\begin{array}{l}3.1 \pm \\
1.3\end{array}$ \\
\hline & & Lan & $0.58 \pm 0.30$ & $0.16 \pm 0.09$ & $\begin{array}{l}4.4 \pm \\
0.7\end{array}$ & $0.04 \pm 0.01$ & $0.02 \pm 0.01$ & $\begin{array}{l}3.4 \pm \\
0.6\end{array}$ \\
\hline & \multirow[t]{3}{*}{ NPK } & LO & $\begin{array}{l}0.59 \pm \\
0.14 A\end{array}$ & $\begin{array}{l}0.25 \pm \\
0.18 A\end{array}$ & $\begin{array}{l}3.0 \pm \\
1.2 \mathrm{~B}\end{array}$ & $\begin{array}{l}0.21 \pm \\
0.19 a A\end{array}$ & $\begin{array}{l}0.13 \pm \\
0.11(\mathrm{a}) A\end{array}$ & $\begin{array}{l}3.7 \pm \\
2.6\end{array}$ \\
\hline & & Lan & $0.68 \pm 0.31$ & $\begin{array}{l}0.21 \pm \\
0.08 A\end{array}$ & $\begin{array}{l}4.1 \pm \\
1.4\end{array}$ & $\begin{array}{l}0.05 \pm \\
0.01 \mathrm{~b} B\end{array}$ & $\begin{array}{l}0.012 \pm \\
0.004(\mathrm{~b}) B\end{array}$ & $\begin{array}{l}4.1 \pm \\
1.4 A\end{array}$ \\
\hline & & Lal & $0.48 \pm 0.13$ & $\begin{array}{l}0.15 . \pm \\
0.07\end{array}$ & $\begin{array}{l}3.4 \pm \\
1.0\end{array}$ & $0.05 \pm 0.01 b$ & $\begin{array}{l}0.017 \pm \\
0.007(b)\end{array}$ & $\begin{array}{l}3.4 \pm \\
1.0\end{array}$ \\
\hline
\end{tabular}

\subsection{Rare earth element concentrations in different plant parts}

Considering both substrate types, all culture forms and fertilizer treatments, concentrations of REEs were constantly higher in leaves compared to the stems with LREE/HREEs > 1 (Table 6). On substrate A leaf concentrations were $442 \%$ (LREEs) and 140\% (HREEs) higher than in stems $(p<0.01)$. Also, the LREE/HREE ratio was $46 \%$ higher in leaves than in stems ( $p$ <.01). On substrate B leaf concentrations were 540\% (LREE) and 280\% (HREE) higher in leaves than in stems $(p<0.01)$ with very similar LREE/HREE-ratio among the two plant compartments. The addition of P-fertilizer did not affect the concentrations of REEs directly (Tables 4 and 6). However, there were significant interaction effects between Papplication and culture form influencing the REE concentrations in leaves as well as P-application $\times$ culture interactions influencing the REE concentrations in the stems. Overall, the growth substrate strongly affected REE concentrations in leaves but not of stems with a more strongly pronounced effect on LREE $(p<0.01)$ than on HREE $(p=0.05)$. Considering data from all mixed culture forms and P-fertilizer treatments, leaf concentrations on substrate B were 64\% (LREE) and $72 \%$ (HREE) higher $(p<0.05)$ than on substrate A but with similar LREE/HREE ratio. Application of P-fertilizer in monoculture significantly decreased LREE concentrations of leaves (by 48\%) and LREE and HREE concentrations of stems both by $50 \%$ on substrate $A$, while on substrate $B$ this effect was not observable. Also, in the mixed cultures there was no direct effect of P-application and there were no differences in element concentrations between mixed cultured 
plants that received different fertilizers. Moreover, plants that received only low doses of $\mathrm{P}(\mathrm{NK})$ showed no differences in elemental composition between monocultures and mixed cultures. However, on substrate A, mixed cultures of barley with L. angustifolius that were treated with P-fertilizer responded by a significant increase in concentrations of LREEs by $113 \%$ and HREE by $88 \%$ in leaves and $225 \%$ (LREE) and 200\% (HREE), respectively in stems compared to the monocultures.

On substrate A, L. albus did not alter the mineral composition of the mixed cultured plants, irrespective of the Papplication. In contrast, on substrate B, NPK treated mixed cultures with both L. albus and L. angustifolius significantly decreased the REE concentrations by a factor of four in the case of LREEs or even roughly one order of magnitude in case of HREEs. It has to be noticed that these effects were only prevailing on the slightly alkaline substrate A when plant stands of barley and mixed cultures of barley and L. angustifolius were treated with higher doses of P-fertilizer.

\subsection{Accumulation of nutrients and REEs}

Considering the biomass of leaves and stems and the herein quantified element concentrations, amounts of elements in the respective plant tissues and whole shoot contents were calculated (Fig. 1 and Fig. 2). Plant leaves consistently contained significantly $(p<0.01)$ higher amounts of $\mathrm{Ca}(30 \%), \mathrm{Mn}(44 \%)$, Fe (87\%) and especially of LREEs (265\%) and HREEs (158\%) than stems, except $P$ which predominantly accumulated in plant stems with $78 \%$ higher amounts than in leaves. The growth substrate strongly influenced the element contents in leaves showing significantly higher amounts of all investigated elements in leaves of plants cultivated on substrate B compared to substrate A (Table 7). In stems only contents of $\mathrm{P}$ and $\mathrm{Mn}$ were influenced by a general substrate effect (Table 7). Considering all P-addition levels and culture forms, plants cultivated on substrate B contained $57 \%(\mathrm{P}), 73 \%(\mathrm{Ca}), 251 \%(\mathrm{Mn}), 97 \%(\mathrm{Fe})$ as well as $158 \%$ (LREEs) and $145 \%$ (HREEs) more of the investigated elements in the leaves. Additionally, the plants showed 43\% (P) and 160\% (Mn) more of the elements in stems on substrate B compared to substrate A without an effect from the substrate on $\mathrm{Ca}$, Fe, LREE and HREEs in this plant tissue. Consequently, element contents in shoots that integrate results from both leaves and stems, respectively, were also affected by substrate showing higher contents of P (10\%), Ca (18\%), Mn (170\%), Fe (23\%) and LREEs (60\%) and HREEs (13\%) in shoots of plants that were cultivated on substrate B compared to plants on substrate $A$.

The element contents in shoot biomass were not influenced by general effects of culture form and P-fertilizer addition but rather depended on complex responses of different levels of plant tissue accumulation based on interactions of culture form and substrate properties as well as additional interaction effects of P-fertilizer amendment (Table 7). Specifically, compared to $L$. angustifolius, intercropping with $L$. albus did not positively affect the accumulation of the investigated elements except that of $\mathrm{Mn}$ in leaves and shoots of barley plants on substrate B. On substrate B the presence of $L$. albus increased $\mathrm{Mn}$ content in leaves by $116 \%$ and in shoots by $63 \%$ compared to monocultures, while on substrate A $L$. albus increased the leaf Mn contents by $102 \%$ compared to monocultures. However, for LREEs and HREEs L. albus significantly decreased the element contents in shoots (by $68 \%$ and $71 \%$ respectively) and leaves (by $36 \%$ and $46 \%$, respectively) when the plants grew on substrate B with high P-addition, while on substrate A no effect of $L$. albus on REE accumulation in mixed cultured barley was observed.

Unfortunately, in this study, L. albus was solely cultivated on the two substrates with high dosing of P-fertilizer and thus further evaluations of responses of the mixed cultures to different P-availability are not possible. However, considering mixed cultures with $L$. angustifolius the effect of intercropping on element accumulation was strongly dependent on the growth substrate and P-fertilizer addition. More specifically, on both substrates, there was no response of mixed cultured barley regarding the contents of $\mathrm{P}, \mathrm{Ca}, \mathrm{Mn}$, Fe when barley and $L$. angustifolius were cultivated with high supply of $\mathrm{P}$ (NPKtreatment). In contrast, when P-supply was reduced (NK-treatment) and barley was cultivated neighbouring to $L$.

angustifolius, shoot contents of $\mathrm{P}, \mathrm{Mn}$ and Fe increased on substrate $\mathrm{A}$ by $64 \%(\mathrm{P}), 56 \%(\mathrm{Mn})$, and $62 \%(\mathrm{Fe})$. This was mostly caused by a significant increase in leaf contents, except for $\mathrm{P}$, whereas on substrate $\mathrm{B}$ the shoot contents of $\mathrm{P}$, Mn and Fe decreased by $37 \%(\mathrm{P}), 50 \%(\mathrm{Mn})$ and $37 \%(\mathrm{Fe})$, respectively, due to decreased accumulation in stems and leaves.

Page $12 / 24$ 
Concomitantly, on substrate B there were clear tendencies of a reduction of shoot LREE (by $44 \%$ ) and HREE (by $46 \%$ ) accumulation when plants were cultivated with $L$. angustifolius and low P-dosing compared to the monocultures. Under these conditions $L$. angustifolius significantly reduced LREE contents in stems of barley by $69 \%$. Also, on substrate B the presence of $L$. angustifolius significantly reduced stem contents of HREEs by $46 \%$ in high P-dosed mixed cultures compared to the monocultures but without striking effects on bulk shoot contents which remained unchanged.

In contrast, on substrate A, mixed cultures with L. angustifolius significantly increased contents of LREEs (by $79 \%$ ) and HREEs (by $96 \%$ ) in shoots of barley compared to the monocultures. This can be attributed to a combination of increasing contents in leaves (60\% increase for LREEs and $50 \%$ increase for HREEs) and in stems $(169 \%$ increase for LREEs and $263 \%$ increase for HREEs) when high doses of $P$ were given. For HREEs, this effect was also visible in leaves of plants that were treated with low P-doses (62\% increase) but the effect in leaves was not strong enough to influence bulk shoot contents of HREEs that remained unchanged compared to the monocultures and, due to a decrease in stem HREES contents, there was no effect on LREEs plant stands treated with low P-doses.

Table 7

Multifactor multivariate ANOVA based on leaf and stem contents $\left(\mu \mathrm{g} \mathrm{m}^{-2}\right)$ of barley plants exploring for effects of the growth substrate, fertilizer (P+; $\mathrm{P}-$ ) addition and culture form (mono and mixed cultures). $\left.{ }^{\star}\right) \mathrm{p}<0.1 ;{ }^{*} \mathrm{p}<0.05 ;{ }^{\star \star} \mathrm{p}<0.01$; NS not significant.

\begin{tabular}{|c|c|c|c|c|c|c|c|}
\hline Plant tissue & Source of variation & $\mathbf{P}$ & $\mathrm{Ca}$ & Mn & $\mathrm{Fe}$ & LREE & HREE \\
\hline \multirow[t]{6}{*}{ Leaves } & Substrate & * & $\star *$ & $\star \star \star ~$ & ** & ** & $\star *$ \\
\hline & Fertilizer & NS & NS & NS & NS & NS & NS \\
\hline & Culture & NS & 0.08 & $\star \star$ & NS & $(*)$ & * \\
\hline & Substrate*Culture & NS & NS & NS & NS & NS & $(*)$ \\
\hline & Fertilizer*Culture & NS & NS & NS & NS & NS & NS \\
\hline & Substrate*Fertilizer*Culture & $(*)$ & NS & * & $(*)$ & NS & NS \\
\hline \multirow[t]{6}{*}{ Stems } & Substrate & $(*)$ & NS & 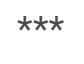 & NS & NS & $(*)$ \\
\hline & Fertilizer & NS & NS & NS & NS & NS & NS \\
\hline & Culture & NS & NS & NS & NS & NS & NS \\
\hline & Substrate*Culture & ** & NS & $(*)$ & NS & * & * \\
\hline & Fertilizer*Culture & NS & NS & NS & NS & $(*)$ & NS \\
\hline & Substrate*Fertilizer*Culture & NS & NS & NS & $(*)$ & NS & NS \\
\hline \multirow[t]{6}{*}{ Shoots } & Substrate & $(*)$ & $(*)$ & $\star \star \star$ & $(*)$ & * & $(*)$ \\
\hline & Fertilizer & NS & NS & NS & NS & NS & NS \\
\hline & Culture & NS & NS & NS & NS & NS & NS \\
\hline & Substrate*Culture & ** & * & ** & $(*)$ & ** & $\star *$ \\
\hline & Fertilizer*Culture & NS & NS & NS & NS & NS & NS \\
\hline & Substrate*Fertilizer*Culture & * & NS & * & * & NS & NS \\
\hline
\end{tabular}

\subsection{Phosphorus concentrations in lupin plants as affected by substrate and P-supply}


Mixed cultures of barley and lupins that received only low doses of $\mathrm{P}\left(1 \mathrm{~g} \mathrm{P} \mathrm{m}^{-2}\right)$ did not show significant differences in leaf $P$ concentrations when plants cultivated on substrate A and B were compared (Fig. 3). Nevertheless, $P$ concentrations in plants on substrate B were slightly higher $\left(2.3 \mathrm{mg} \mathrm{g}^{-1}\right)$ compared to lupins cultivated on substrate $\mathrm{A}\left(1.9 \mathrm{mg} \mathrm{g}^{-1}\right)$. Generally, on both substrates fertilization of the mixed cultures with P-fertilizer significantly increased the concentrations of $P$ and his effect was most visible on substrate $B$ where NPK treated plants reached up to $3.1 \mathrm{mg} \mathrm{g}^{-1} \mathrm{P}$ in leaves. Here, plants of $L$. angustifolius displayed substantially higher $\mathrm{P}$ concentrations than plants on substrate A. L. albus was only cultivated under NPK addition of substrate $A$ and thus investigations of responses of the species to substrate and Psupply were not possible. Compared to L. angustifolius, L. albus exhibited similar P concentrations when both species received NPK fertilizer (Fig. 3).

\section{Discussion}

\subsection{Evaluation of carboxylate release in different lupin species}

In the greenhouse experiment exudation experiment was carried out as a means to evaluate the carboxylate release and consequently the nutrient acquisition efficiency of the cultivars of L. albus (Feodora) and L. angustifolius (Sonate) that were later used in the field experiment for intercropping with barley. Lupins are characterized by an extraordinarily high efficiency to mobilize sparingly available $\mathrm{P}, \mathrm{Fe}$ and $\mathrm{Mn}$ in the rhizosphere through carboxylate release and acidification which is extensively documented in the literature (Cu et al. 2005; Lambers et al. 2013; Pearse et al. 2006; Wiche et al. 2016b), while barley is described as P-inefficient (Marschner 1995). The results successfully demonstrate that the response of the two species was divergent (Table 3 ) showing a higher release of carboxylates in L. albus under P-deficient conditions, whereas $L$. angustifolius responded with decreased release of carboxylates (Table 3 ) and highest exudation rates under high P-supply. For $L$. albus, this is in congruency with the results from Pearse et al. (2006), Müller et al. (2015) and Neumann and Römheld (2000) who reported increased diffusion of citrate and malate as a consequence of metabolic shifts in carbohydrate allocation from shoot to roots in concert with increased biosynthesis of malate and citrate and decreased citrate turnover in the tricarboxylic acid cycle. Concomitantly, the decreased release of carboxylates in $L$. angustifolius suggests that this species (or the selected cultivar) lacks the ability to alter carboxylate metabolism following P-deficiency similar to chickpea (Pearse et al. 2006). Based on the above it seems that $L$. albus should be preferably selected for intercropping aiming at improved plant nutrition in mixed culture systems, especially when plant growth is limited by P-availability. Indeed, the total amounts of carboxylates released per plant were higher in $L$. albus whereas the exudation rates (per root dry weight) of both lupin species were similar under low P supply (Table 3) which can be explained by thicker roots and consequently a higher total root dry mass relative to the number of active root tip regions of L. albus (Egle et al. 2003) compared to L. angustifolius. However, when the plants were adequately supplied with P, L. angustifolius showed substantially higher carboxylate exudation rates and amounts of citrate released per plant individual compared to $L$. albus which highlights the high potential applicability of this $L$. angustifulius cultivar for improvement of nutrient supply for mixed culture cropping with nutrient inefficient species on moderately fertile soils.

\subsection{Effect of substrate properties on plant growth and nutrient availability to the plants}

Considering the leaf nutrient concentrations which are commonly used as proxies for the nutritional state of plants (Hayes et al. 2014) it was obvious that on both substrates the barley plants suffered from Mn and P deficiency indicated by leaf $\mathrm{P}$ concentrations close or even below to the critical value of $2 \mathrm{mg} \mathrm{g}^{-1} \mathrm{P}$ and $50 \mu \mathrm{g} \mathrm{g}^{-1} \mathrm{Mn}$ (Marschner 1995). The lowest concentrations of $\mathrm{P}$ and $\mathrm{Mn}$ (below $1.9 \mathrm{mg} \mathrm{g}^{-1} \mathrm{P}$ and $20 \mathrm{\mu g} \mathrm{g}^{-1} \mathrm{Mn}$ ) were observed in plants on substrate $A$ treated with low P-doses (Table 5). Surprisingly, comparing leaf, stem and shoot biomass on both substrates we did not observe significant changes in plant yields between the substrates (Tables 4, 5). Compared to substrate A, concentrations in barley leaves as well as bulk shoot contents (Fig. 1, Table 5), were significantly higher on substrate B, indicating an improved nutrient supply on this substrate with its slightly acidic $\mathrm{pH}$. Furthermore, on substrate $\mathrm{B}$ leaf $\mathrm{P}$ concentration of 
lupin plants were significantly higher than on substrate A and significantly higher compared to H. vulgare (Table 5, Fig. 3) while on substrate A leaf $\mathrm{P}$ concentration in unfertilized plants of $L$. angustifolius were similar to $H$. vulgare. Higher nutrient concentrations in lupins compared to $H$. vulgare can be explained by a higher nutrient acquisition efficiency of lupins (Pearse et al. 2006). Based on P concentrations determined by CAL-extracts both substrates were sufficiently supplied with P (Marschner 1995) but the phosphorus was most likely not present in plant-available forms. Substrate A was slightly alkaline ( $\mathrm{pH}$ 7.9) (Table 1) which fosters the precipitation of sparingly soluble Ca-phosphates (Mengel et al. 2001) and low solubility of Mn and Fe. In contrast, soil B was slightly acidic (pH 6.8) (Table 1) so that low specific sorption of $\mathrm{P}$ (Mengel et al. 2001) as well as higher solubility of Mn and Fe can be expected (Gupta and Chipman 1976). Generally, higher accumulation and concentrations of the nutrients on substrate B was not surprising (Fig. 1, Table 7). However, the higher availability of the elements on substrate B exhibited by higher tissue concentrations and shoot contents was not a priori predictable based on data of the sequential extraction where substrate A showed lower concentrations of $\mathrm{P}, \mathrm{Ca}, \mathrm{Mn}$, Fe in mobile, exchangeable fractions (Table 2). On the contrary, substrate $\mathrm{B}$ was characterized by higher concentrations of $\mathrm{P}, \mathrm{Fe}$ and $\mathrm{Mn}$ bound into organic matter and amorphous Fe-oxyhydroxides (Table 2). This demonstrates that sequential extractions do not sufficiently describe the availability of elements since they do not integrate all soil-associated factors and plant-associated factors overlapping in the rhizosphere in time, space and function (Hinsinger et al. 2009; Vetterlein et al. 2020). This suggests that in this experiment the higher availability of nutrients on substrate B rather depended on the mobility of the elements in the soil (once they are mobilized) as a consequence of $\mathrm{pH}$ and thus, a lower reprecipitation/ readsorption of mobilized elements in the rhizosphere of the plants than distribution of elements in operationally defined element fractions. In this light, we emphasize that CAL-extracts (Table 1) exhibited a higher $P$ availability on substrate $B$ which was in agreement with the substrate-induced differences in tissue $\mathrm{P}$ concentrations in plants. This suggests that both the CAL-extractant solutions (acidified Ca-lactate), as well as the plants, were able to access moderately stable element pools through acidification and ligand-exchange reactions, especially the lupins with their efficient acquisition strategy.

4.3 Relationships between the substrate, P-fertilization and lupins on plant growth and nutrient availability in mixed cultures

In this experiment, we used a replacement model, where within the mixed cultures, barley was replaced with $11 \%$ of $L$. albus and L. angustifolius (Wiche et al. 2016a). Although there were slight reductions in yields following a replacement, growth substrate, different levels of P-supply and intercropping did not affect plant yields of barley. With the exception of substrate $A$ and on plots with low P-fertilizer amendment, intercropping with L. angustifolius slightly increased the leaf biomass of barley (Table 5). Of course, plant growth and yield predominantly depend on the nutritional state of the plants which was experimentally controlled by substrate properties, the addition of P-fertilizer and intercropping with lupins. Moreover, the efficiency of intercropping strongly depends on the nutritional status of the lupin plants because under conditions of adequate nutrient availability below ground traits of intercropping plants may not deliver additional benefits. Thus, positive effects of intercropping can be especially expected under conditions of moderate to low nutrient availability. However, under conditions of growth limitation neighbouring plants with more efficient nutrient acquisition efficiency initially satisfy their own nutrient demands. This may lead to root competition for resources and only sharing elements with neighbouring plants after own nutritional demands are satisfied (Cu et al. 2005; Gunes and Inal 2009; Wiche et al. 2016b)

In our experiment, the addition of the P-fertilizer did not influence the $\mathrm{P}$ concentrations and contents of barley plants neither on substrate $A$ nor on substrate $B$ (Tables 4 and 5). Possibly, the doses were not high enough $\left(1 \mathrm{~g} \mathrm{~m}^{-2}\right.$ or $3 \mathrm{~g} \mathrm{~m}^{-2}$ P) to improve the plants' nutrient supply due to a fast P fixation e.g. as Ca-phosphates on substrate A so that it was not available for barley and/or the lupin plants strongly competed with barley for phosphate. P concentrations in lupins significantly increased when $\mathrm{P}$ was added (Fig. 3) indicating a strong root competition for essential elements between lupins and barley. Finally, resource facilitation in mixed cultures strongly depends on the nutrient status of the lupin 
plants, their responses through the release of carboxylates influencing the solubility of the elements in the rhizosphere and migration of elements between the intermingling root systems (Cu et al. 2005; Wiche et al. 2016a; Wiche et al. 2017a). The availability of $P$ and micronutrients was higher in substrate $B$ than on substrate $A$ (Table 1, Fig. 1). Therefore, the low performance of $L$. angustifolius and $L$. albus in mixed cultures with barley on substrate B (Fig. 1, Table 5) could be explained by the synergetic effects of reduced carboxylate release by the lupins, especially of L. albus (Table 3), and higher substrate-induced solubility of the elements fostering element uptake by the barley plants. Nevertheless, increased Mn concentrations and accumulation (Fig. 1, Table 5) in mixed cultured on substrate B indicate that cluster roots of $L$. albus were still active even when P-fertilizer was added. It has to be noticed that even on substrate $B$ the plants were still undersupplied with $\mathrm{Mn}$ (Table 5, Section 4.2) which is an additional factor triggering carboxylate release by lupins (Lambers et al. 2013; Lambers et al. 2015; Marschner and Römheld 1994). Concomitantly, carboxylates of L. albus are known to strongly affect the availability of $\mathrm{Mn}$ as this species is considered a hyperaccumulator of Mn (Lambers et al. 2015). In this regard, lacking effects in mixed cultures with $L$. angustifolius might indicate a lower ability of $L$. angustifolius to respond to deficiency of $\mathrm{Mn}$, while decreased accumulation of $\mathrm{P}$ and $\mathrm{Mn}$ in presence of $L$. angustifolius could be due to competition of barley and lupins for these nutrients.

On substrate A, intercropping with $L$. angustifolius slightly increased leaf P concentrations of low P-dosed plants above the critical level of $2 \mathrm{mg} \mathrm{g}^{-1}$ suggesting that the improved nutritional state of the barley plants was responsible for the increase in leaf biomass (Table 5). On this alkaline substrate, leaf and shoot nutrient concentrations and contents of barley were exclusively positively affected (Table 5, Fig. 1) on experimental plots with low P-addition although the leaf $P$ concentrations of lupins suggested a lower P-supply in L. angustifolius (Fig. 3) which should lead to decreased root activity of this lupin species (Table 3). However, in plots with a higher P-supply, we observed a better plant growth of lupins (data not shown here) so that it is reasonable that the mobilized nutrients were initially taken up by the lupins without any positive effects on barley. Concomitantly, increased concentrations and accumulation of $\mathrm{Ca}$, $\mathrm{Mn}$ and $\mathrm{Fe}$ in mixed cultures with low P supply (Table 5, Fig. 1) most likely originated from resource facilitation under the growth limiting conditions of substrate $\mathrm{A}$, where neighbouring lupins improved the nutritional status of barley plants.

\subsection{Effect of substrates, P-fertilization and lupins on the availability of REEs in mixed cultures}

In soils, REEs share many chemical similarities with essential plant nutrients, especially calcium (Brioschi et al. 2013; Censi et al. 2014; Censi et al. 2017; Martinez et al. 2018; Wyttenbach et al. 1998). Thus, nutrient bearing soil phases such as phosphates, organic matter and Fe-oxyhydroxides are important hosts for these elements (Diatloff et al. 1993; Zhimang et al. 2000; Cao et al. 2001; Wiche and Heilmeier 2016; Wiche et al. 2016b). Accordingly, in the soil used for the field experiment, REEs were mostly present in fractions 3-5 and with slight enrichment in fraction 3 of substrate B (Table 2). Low soil pH and the presence of dissolved organic matter strongly impact mobility and plant availability of REEs (Cao et al. 2001; Diatloff et al. 1993; Pourret et al. 2007; Tyler and Olsson 2001; Zhimang et al. 2000). As such, the higher concentrations (Table 6) and accumulation (Fig. 2) of REEs on substrate B in comparison to substrate A can be attributed to a higher solubility of the elements in this soil. Higher accumulation of LREEs relative to HREEs observed in this study (Table 6, Fig. 2) closely follow the natural abundance of the elements in the substrates (Table 3). Furthermore, the literature indicates a preferential uptake of LREEs compared to HREEs (Censi et al. 2017, Martinez et al. 2018) due to higher stability of HREE-organic complexes and stronger adsorption of HREEs at ion exchange sites in the soil. These, in turn, may have contributed to these results. Surprisingly, in this study leaf concentrations of REEs were constantly higher than in the stems and the plants mostly responded by changes in leaf REE concentrations (Table 6) which contradicts the findings of Brioschi et al. (2013) and Tyler et al. (2004) who demonstrated decreasing concentrations in the order roots > stems $>$ leaves. A similar order demonstrating REE concentrated in plants as root $>$ leaf $>$ stem $>$ grain was observed by Li et al. (2001), Wen et al. (2001) Yuan et al. (2018) and Xu et al (2003). This suggests that either species-specific or cultivarspecific traits that we did not consider in this study influenced the REE distribution in our plants. Nonetheless, we

Page $16 / 24$ 
emphasize that differences in substrates as well as intercropping with lupins impacted both leaf and bulk shoot contents of barley (Fig. 2) although in barley the predominant portion of the shoot biomass consisted of stems (Table 5). Leaves only accounted for one-third of the total shoot biomass (Table 5) and changes in foliar REE absorption due to treatment measures was impactful enough to compensate the lower biomass of this plant part when total shoot contents are considered (Fig. 2). Similar to the findings for nutrients (see Section 4.2), REE concentrations on substrate B were predominantly influenced by substrate without significant effects of P-fertilizer addition or presence of lupins in mixed cultures. However, on substrate B presence of L. albus significantly decreased both shoot REE concentrations and contents, especially when the plants were fertilized with P which highlights an immobilization or uptake of the elements by the lupins under conditions where mobility of the elements is high. Unfortunately, our experimental design did not allow to explore the processes beyond these effects. On the alkaline substrate A, the addition of P-fertilizer significantly reduced both LREE and HREE concentrations in monocultured barley plants (Table 6). This can be attributed to a precipitation of the elements as hardly soluble REE-phosphates at alkaline conditions (Saatz et al. 2016, Han 2020) or a "dilution" effect originating from slightly higher shoot biomass (Table 5) which is frequently reported for non-essential elements (Chien and Menon 1995). Compared to the monocultures, the presence of L. angustifolius significantly increased tissue concentrations and shoot contents of both LREEs and HREEs in mixed cultured barley. Increased REE availability in mixed cultures with lupins was already described by Wiche et al. (2016b) but without considering differences in substrates or nutrient availability. In the present study positive effects of mixed cultures were only visible on the alkaline, P-fertilizer amended soil and in presence of $L$. angustifolius which releases higher carboxylates under sufficient P-supply (Table 3). Most probably, under these conditions the carboxylates released by lupins mobilized the REEs through formation of soluble REE-carboxylate complexes (Wiche et al. 2017a) in the rhizosphere of the lupins. Since REEs are not essential for plant growth and complexes of REEs are discriminated relative to their ionic forms during plant uptake (Han et al. 2005; Wiche et al. 2017a) the complexes were obviously not adsorbed by the lupins itself enabling the movement to the intermingling barley roots where different chemical properties might have fostered the decay of complexes and thus root uptake and transport of REEs to the shoots.

\section{Conclusion}

We could demonstrate that mixed cultures of barley with L. angustifolius cv. Sonate increased the accumulation of REEs in barley plants when the plants were additionally supplied with P-fertilizer and cultivated on an alkaline soil characterized by low initial availability of REEs and nutrients. In contrast, on soil with high REE mobility, the presence of $L$. albus cv. Feodora led to decreased REE contents in barley. This highlights the importance of considering plant physiology, nutritional status of neighbouring plants and general substrate chemistry when soil-plant transfer of REEs in mixed culture plants stands or plant communities are subject of evaluation. Considering these factors, mixed culture cropping systems could be a powerful tool to enhance accumulation of REEs in a sense of phytoremediation or phytomining on marginal soils, while at the same time the mixed cultures with L. albus cv. Feodora could be deployed to cope with REE accumulation in crop plants for food production, especially in REE-polluted soils. The processes involved in the results are not yet fully understood, and thus, elucidation of chemical element species in the rhizosphere of neighbouring plants remains a field of further research. Nevertheless, our findings suggest that interspecific root interactions between legumes and grasses impact the soil-plant transfer not only of nutrients but also the nutrient-like rare earth elements which will improve our general understanding of the biogeochemical cycling of these elements in (agro)ecosystems and legumegrass communities.

\section{Declarations}

\section{Acknowledgement}


The authors acknowledge the financial support and funding from the European Regional Development Fund under the Dora Plus action

\section{Funding}

This work was supported by the European Regional Development Fund under the Dora Plus action. Monei N.L has received research support from this funding scheme for her doctoral studies.

\section{Competing interests:}

The authors have no relevant financial or non-financial interests to disclose, there are also no conflicts among the authors who have contributed to the preparation of this manuscript.

\section{Ethical approval}

The authors declare that this work is original, has not been published previously and is not under consideration for publication elsewhere. The authors declare that this work fulfils the good scientific practice according to the Committee on Publication Ethics (COPE).

\section{Research involving human participants and/or animals}

Not applicable

\section{Declaration of consent to participate}

All authors made substantial contributions to the conception or design of the work, analysis and interpretation of data. All authors drafted the work or revised it critically for important intellectual content.

\section{Declaration of consent to publish}

All authors approved the version to be published and agreed with the content, gave explicit consent to submit and obtained consent from the responsible authorities at the institute/organization where the work has been carried out. All authors agreed to be accountable for all aspects of the work.

\section{Author contributions}

All authors contributed to the study conception and design. Material preparation, data collection and analysis were performed by Oliver Wiche, Nthati Monei and Juliane Heim. The first draft of the manuscript was written by Nthati Monei and Oliver Wiche. Both authors contributed equally towards data analysis and writing the manuscript. Michael Mitch, Hermann Heilmeier and Olivier Pourret commented on previous versions of the manuscript, interpreted results and acquired funding. All authors read and approved the final manuscript.

\section{Availability of data and materials}

Not applicable. Raw data (primary data obtained from HPLC or ICP-MS) has not been considered for publication in data repositories.

\section{References}

1. Bolleter WT, Bushman CJ, Tidwell PW (1961) Spectrophotometric Determination of Ammonia as Indophenol. Anal Chem 33(4):592-594. https://doi.org/10.1021/ac60172a034 
2. Brioschi L, Steinmann M, Lucot E, Pierret MC, Stille P, Prunier J, Badot PM (2013) Transfer of rare earth elements (REE) from natural soil to plant systems: implications for the environmental availability of anthropogenic REE. Plant Soil 366(1-2):143-163. https://doi.org/10.1007/s11104-012-1407-0

3. Cao X, Chen Y, Wang X, Deng X (2001) Effects of redox potential and pH value on the release of rare earth elements from soil. Chemosphere 44(4):655-661. https://doi.org/10.1016/S0045-6535(00)00492-6

4. Censi P, Raso M, Yechieli Y, Ginat H, Saiano F, Zuddas P, Brusca L, D’Alessandro W, Inguaggiato C (2017) Geochemistry of $\mathrm{Zr}, \mathrm{Hf}$, and REE in a wide spectrum of Eh and water composition: The case of Dead Sea Fault system (Israel). Geochem Geophys Geosyst 18(3):844-857. https://doi.org/10.1002/2016GC006704

5. Censi P, Saiano F, Zuddas P, Nicosia A, Mazzola S, Raso M (2014) Authigenic phase formation and microbial activity control Zr, Hf, and rare earth element distributions in deep-sea brine sediments. Biogeosciences 11(4):1125-1136. https://doi.org/10.5194/bg-11-1125-2014

6. Chien SH, Menon RG (1995) Factors affecting the agronomic effectiveness of phosphate rock for direct application. Fertilizer Research 41(3):227-234. https://doi.org/10.1007/BF00748312

7. Cu STT, Hutson J, Schuller KA (2005) Mixed culture of wheat (Triticum aestivum L.) with white lupin (Lupinus albus L.) improves the growth and phosphorus nutrition of the wheat. Plant Soil 272(1-2):143-151. https://doi.org/10.1007/s11104-004-4336-8

8. Cunha MdCL, Nardi LV, Muller IF (2012) Biogeochemistry of REE elements and tetrad effect in the soil-plant system: a study on volcanic rock covers in southernmost Brazil 84

9. Davranche M, Gruau G, Dia A, Bouhnik-Le Coz M, Marsac R, Pédrot M, Pourret O (2017) Trace elements in waterlogged soils and sediments

10. Diatloff E, Asher CJ, Smith FW (1993) Use of GEOCHEM-PC to predict rare earth element (REE) species in nutrient solutions. Plant Soil 155/156:251-254

11. Egle K, Römer W, Keller H (2003) Exudation of low molecular weight organic acids by Lupinus albus L., Lupinus angustifolius L. and Lupinus luteus L. as affected by phosphorus supply. Agronomie 23(5-6):511-518. https://doi.org/10.1051/agro:2003025

12. Faucon M-P, Houben D, Reynoird J-P, Mercadal-Dulaurent A-M, Armand R, Lambers H (2015) Chapter Two - Advances and Perspectives to Improve the Phosphorus Availability in Cropping Systems for Agroecological Phosphorus Management // Advances and Perspectives to Improve the Phosphorus Availability in Cropping Systems for Agroecological Phosphorus Management. In: Sparks DL (ed) Advances in Agronomy, vol 134. Academic Press, pp 51-79

13. Gunes A, Inal A (2009) Phosphorus Efficiency in Sunflower Cultivars and Its Relationships with Phosphorus, Calcium, Iron, Zinc and Manganese Nutrition. J Plant Nutr 32(7):1201-1218. https://doi.org/10.1080/01904160902945325

14. Gupta UC, Chipman EW (1976) Influence of iron and pH on the yield and iron, manganese, zinc, and sulfur concentrations of carrots grown on sphagnum peat soil. Plant Soil 44(3):559-566. https://doi.org/10.1007/BF00011375

15. Han F, Shan X, Zhang J, Xie Y-N, Pei Z-G, Zhang S, Zhu Y-G, Wen B (2005) Organic acids promote the uptake of lanthanum by barley roots. New Phytol 165(2):481-492. https://doi.org/10.1111/j.1469-8137.2004.01256.X

16. Han KN (2020) Characteristics of Precipitation of Rare Earth Elements with Various Precipitants. Minerals 10(2):178. https://doi.org/10.3390/min10020178

17. Hartley AM, Asai RI (1963) Spectrophotometric Determination of Nitrite as 4-Nitroso-2, 6-xylenol. Anal Chem 35(9):1214-1218. https://doi.org/10.1021/ac60202a002

18. Hayes $P$, Turner BL, Lambers H, Laliberté E (2014) Foliar nutrient concentrations and resorption efficiency in plants of contrasting nutrient-acquisition strategies along a 2-million-year dune chronosequence. J Ecol 102(2):396-410. 
https://doi.org/10.1111/1365-2745.12196

19. Kabata-Pendias A (2010) Trace elements in soils and plants, Fourth edition. CRC Press, Boca Raton, FL

20. Krasilnikoff G, Gahoonia T, Nielsen NE (2003) Variation in phosphorus uptake efficiency by genotypes of cowpea (Vigna unguiculata) due to differences in root and root hair length and induced rhizosphere processes. Plant Soil 251(1):83-91. https://doi.org/10.1023/A:1022934213879

21. Lambers H, Clements JC, Nelson MN (2013) How a phosphorus-acquisition strategy based on carboxylate exudation powers the success and agronomic potential of lupines (Lupinus, Fabaceae). Am J Bot 100(2):263-288. https://doi.org/10.3732/ajb.1200474

22. Lambers H, Hayes PE, Laliberté E, Oliveira RS, Turner BL (2015) Leaf manganese accumulation and phosphorusacquisition efficiency. Trends Plant Sci 20(2):83-90. https://doi.org/10.1016/j.tplants.2014.10.007

23. Li F, Shan X, Zhang S (2001) Evaluation of single extractants for assessing plant availability of rare earth elements in soils. Commun Soil Sci Plant Anal 32(15-16):2577-2587. https://doi.org/10.1081/CSS-120000392

24. Li T, Kaercher S, Roesky PW (2014) Synthesis, structure and reactivity of rare-earth metal complexes containing anionic phosphorus ligands. Chem Soc Rev 43(1):42-57. https://doi.org/10.1039/C3CS60163C

25. Marschner H (1995) Mineral Nutrition of Higher Plants, 2nd edn. Elsevier Science \& Technology, San Diego

26. Marschner H, Römheld V (1994) Strategies of plants for acquisition of iron. Plant Soil 165(2):261-274. https://doi.org/10.1007/BF00008069

27. Marschner H, Römheld V, Horst WJ, Martin P (1986) Root-induced changes in the rhizosphere: Importance for the mineral nutrition of plants. J Plant Nutr Soil Sci 149(4):441-456. https://doi.org/10.1002/jpln.19861490408

28. Martinez RE, Pourret O, Faucon M-P, Dian C (2018) Effect of rare earth elements on rice plant growth. Chem Geol 489:28-37. https://doi.org/10.1016/j.chemgeo.2018.05.012

29. McLennan SM (2001) Relationships between the trace element composition of sedimentary rocks and upper continental crust. Geochem Geophys Geosyst 2(4). n/a-n/a https://doi.org/10.1029/2000GC000109

30. Mengel K, Kirkby EA, Kosegarten H, Appel T (2001) Principles of Plant Nutrition. Springer Netherlands, Dordrecht

31. Müller J, Gödde V, Niehaus K, Zörb C (2015) Metabolic Adaptations of White Lupin Roots and Shoots under Phosphorus Deficiency. Front. Plant Sci 6:1014. https://doi.org/10.3389/fpls.2015.01014

32. Neumann G, Massonneau A, Langlade N, Dinkelaker B, Hengeler C, Römheld V, Martinoia E (2000) Physiological Aspects of Cluster Root Function and Development in Phosphorus-deficient White Lupin (Lupinus albus L.). Ann Botany 85(6):909-919

33. Nobile C, Houben D, Michel E, Firmin S, Lambers H, Kandeler E, Faucon M-P (2019) Phosphorus-acquisition strategies of canola, wheat and barley in soil amended with sewage sludges. Sci Rep 9(1):14878.

https://doi.org/10.1038/s41598-019-51204-x

34. Oburger E, Gruber B, Schindlegger Y, Schenkeveld WDC, Hann S, Kraemer SM, Wenzel WW, Puschenreiter M (2014) Root exudation of phytosiderophores from soil-grown wheat. New Phytol 203(4):1161-1174. https://doi.org/10.1111/nph.12868

35. Pearse SJ, Veneklaas EJ, Cawthray G, Bolland MDA, Lambers H (2006) Triticum aestivum shows a greater biomass response to a supply of aluminium phosphate than Lupinus albus, despite releasing fewer carboxylates into the rhizosphere. New Phytol 169(3):515-524. https://doi.org/10.1111/j.1469-8137.2005.01614.x

36. Pourret O, Davranche M, Gruau G, Dia A (2007) Competition between humic acid and carbonates for rare earth elements complexation. J Colloid Interface Sci 305(1):25-31. https://doi.org/10.1016/j.jcis.2006.09.020

37. Reichman SM, Parker DR (2005) Chapter 4 - Metal complexation by phytosiderophores in the rhizosphere.. In: In: Huang PM, Gobran GR (eds) Biogeochemistry of trace elements in the rhizosphere. Elsevier, Amsterdam, Oxford, pp $129-156$

Page 20/24 
38. Saatz J, Stryhanyuk H, Vetterlein D, Musat N, Otto M, Reemtsma T, Richnow HH, Daus B (2016) Location and speciation of gadolinium and yttrium in roots of Zea mays by LA-ICP-MS and ToF-SIMS. Environmental pollution (Barking, Essex: 1987) 216:245-252. https://doi.org/10.1016/j.envpol.2016.05.069

39. Tyler G (2004) Rare earth elements in soil and plant systems - A review. Plant Soil 267(1-2):191-206. https://doi.org/10.1007/s11104-005-4888-2

40. Tyler G, Olsson T (2001) Concentrations of 60 elements in the soil solution as related to the soil acidity. Eur J Soil Sci 52(1):151-165

41. Wang X, Pearse SJ, Lambers H (2013) Cluster-root formation and carboxylate release in three Lupinus species as dependent on phosphorus supply, internal phosphorus concentration and relative growth rate. Ann Botany 112(7):1449-1459. https://doi.org/10.1093/aob/mct210

42. Wen B, Yuan D, Shan X, Li F, Zhang S (2001) The influence of rare earth element fertilizer application on the distribution and bioaccumulation of rare earth elements in plants under field conditions. Chemical Speciation \& Bioavailability 13(2):39-48. https://doi.org/10.3184/095422901783726825

43. Wenzel WW (2009) Rhizosphere processes and management in plant-assisted bioremediation (phytoremediation) of soils. Plant Soil 321(1-2):385-408. https://doi.org/10.1007/s11104-008-9686-1

44. Wiche O, Heilmeier H (2016) Germanium (Ge) and rare earth element (REE) accumulation in selected energy crops cultivated on two different soils. Miner Eng 92:208-215. https://doi.org/10.1016/j.mineng.2016.03.023

45. Wiche O, Kummer N-A, Heilmeier H (2016a) Interspecific root interactions between white lupin and barley enhance the uptake of rare earth elements (REEs) and nutrients in shoots of barley. Plant Soil 402(1-2):235-245. https://doi.org/10.1007/s11104-016-2797-1

46. Wiche O, Székely B, Kummer N-A, Moschner C, Heilmeier H (2016b) Effects of intercropping of oat (Avena sativa L.) with white lupin (Lupinus albus L.) on the mobility of target elements for phytoremediation and phytomining in soil solution. Int J Phytoremediation 18(9):900-907. https://doi.org/10.1080/15226514.2016.1156635

47. Wiche O, Tischler D, Fauser C, Lodemann J, Heilmeier H (2017a) Effects of citric acid and the siderophore desferrioxamine B (DFO-B) on the mobility of germanium and rare earth elements in soil and uptake in Phalaris arundinacea. Int J Phytoremediation 19(8):746-754. https://doi.org/10.1080/15226514.2017.1284752

48. Wiche O, Zertani V, Hentschel W, Achtziger R, Midula P (2017b) Germanium and rare earth elements in topsoil and soil-grown plants on different land use types in the mining area of Freiberg (Germany). J Geochem Explor 175:120129. https://doi.org/10.1016/j.gexplo.2017.01.008

49. Wyttenbach A, Furrer V, Schleppi P, Tobler L (1998) Rare earth elements in soil and in soil-grown plants. Plant Soil 199(2):267-273. https://doi.org/10.1023/A:1004331826160

50. Xu X, Zhu W, Wang Z, Witkamp G-J (2003) Accumulation of rare earth elements in maize plants (Zea mays L.) after application of mixtures of rare earth elements and lanthanum. Plant Soil 252(2):267-277.

https://doi.org/10.1023/A:1024715523670

51. Yuan M, Liu C, Liu W-S, Guo M-N, Morel JL, Huot H, Yu H-J, Tang Y-T, Qiu R-L (2018) Accumulation and fractionation of rare earth elements (REEs) in the naturally grown Phytolacca americana L. in southern China. Int J

Phytoremediation 20(5):415-423. https://doi.org/10.1080/15226514.2017.1365336

52. Zhimang G, Xiaorong W, Jing C, Liansheng W, Lemei D (2000) Effects of sulfate on speciation and bioavailability of rare earth elements in nutrient solution. Chemical Speciation \& Bioavailability 12(2):53-58.

https://doi.org/10.3184/095422900782775544

\section{Figures}

Page $21 / 24$ 
Substrate A
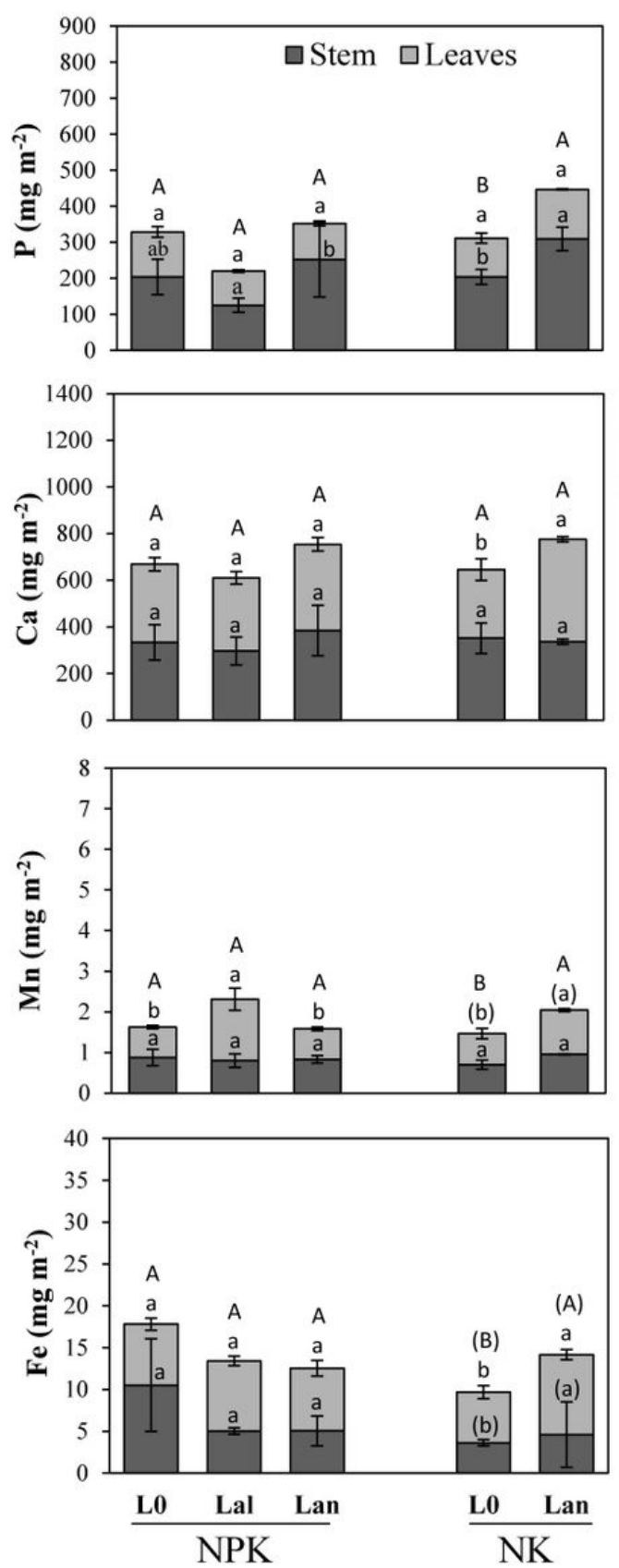

Substrate B
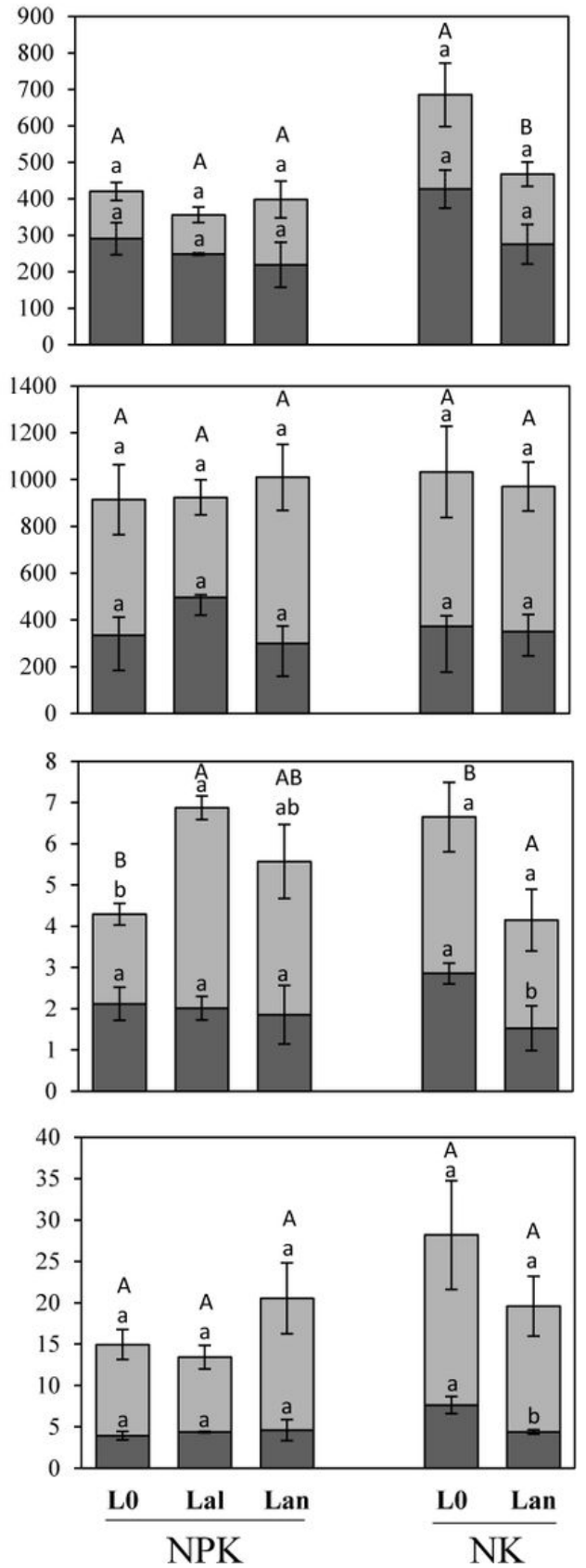

Figure 1

Total accumulation of nutrients in leaves, stems and shoots (total height of bars) of barley plants in monoculture (LO) and mixed cultures with L. angustifolius ( $\mathrm{Lan}$ ) or L. albus ( $\mathrm{Lal}$ ) on the slightly alkaline substrate A and the slightly acidic substrate B. On both substrates the plants in different culture forms were treated with $3 \mathrm{~g} \mathrm{~m}^{-2} \mathrm{P}(\mathrm{NPK})$ or $1 \mathrm{~g} \mathrm{~m}^{-2} \mathrm{P}$ (NK). Means $\pm s d(n=5)$. Differences among means were identified by MANOVA followed by Duncan's post-hoc test. Small letters denote differences in element contents within a specific plant part, substrate and P-addition treatment. Capital letters show differences between shoot contents within the substrates and treatments at $a=5 \%$ 
Substrate A
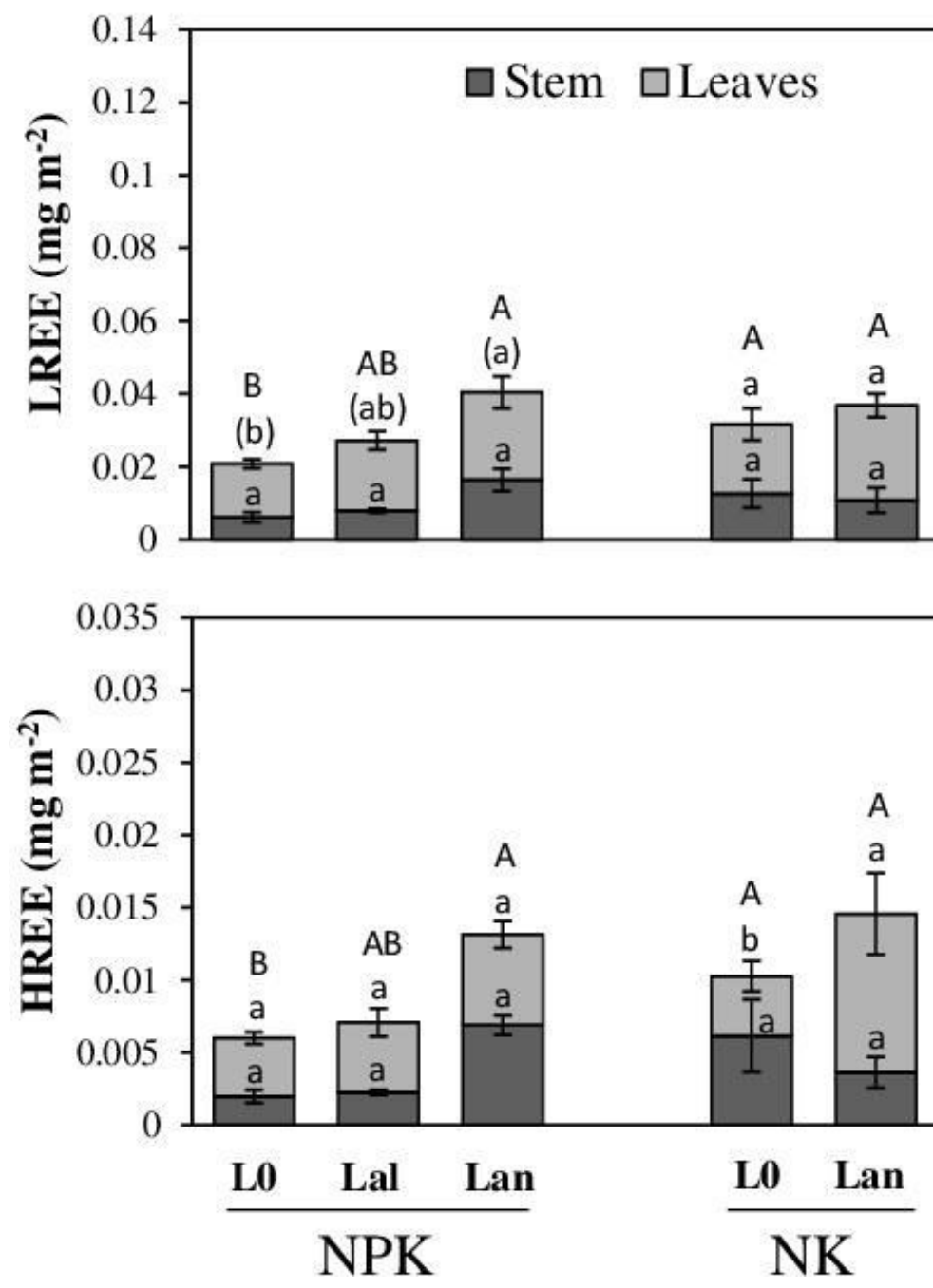

Substrate B
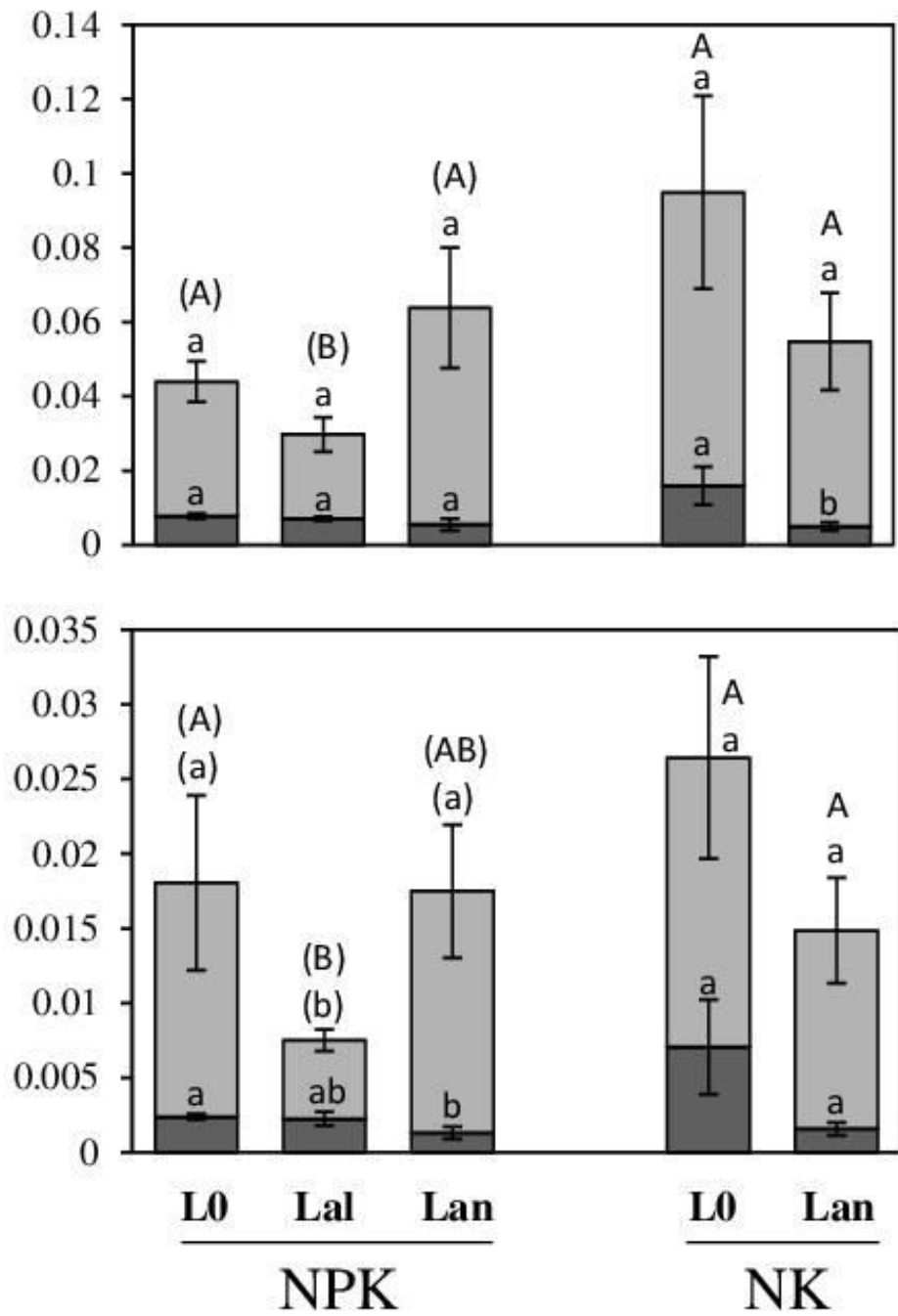

Figure 2

Total accumulation of nutrients in leaves, stems and shoots (total height of bars) of barley plants in monoculture (LO) and mixed cultures with L. angustifolius (Lan) or L. albus (Lal) on the slightly alkaline substrate A and the slightly acidic substrate $B$. On both substrates, the plants in different culture forms were treated with $3 \mathrm{~g} \mathrm{~m}^{-2} \mathrm{P}(\mathrm{NPK})$ or $1 \mathrm{~g} \mathrm{~m}^{-2} \mathrm{P}(\mathrm{NK})$. Means $\pm s d(n=5)$. Differences among means were identified by MANOVA followed by Duncan's post-hoc test. Small letters denote differences in element constants within a specific plant part, substrate and P-addition treatment. Capital letters show differences between shoot contents within the substrates and treatments at $a=5 \%$ 


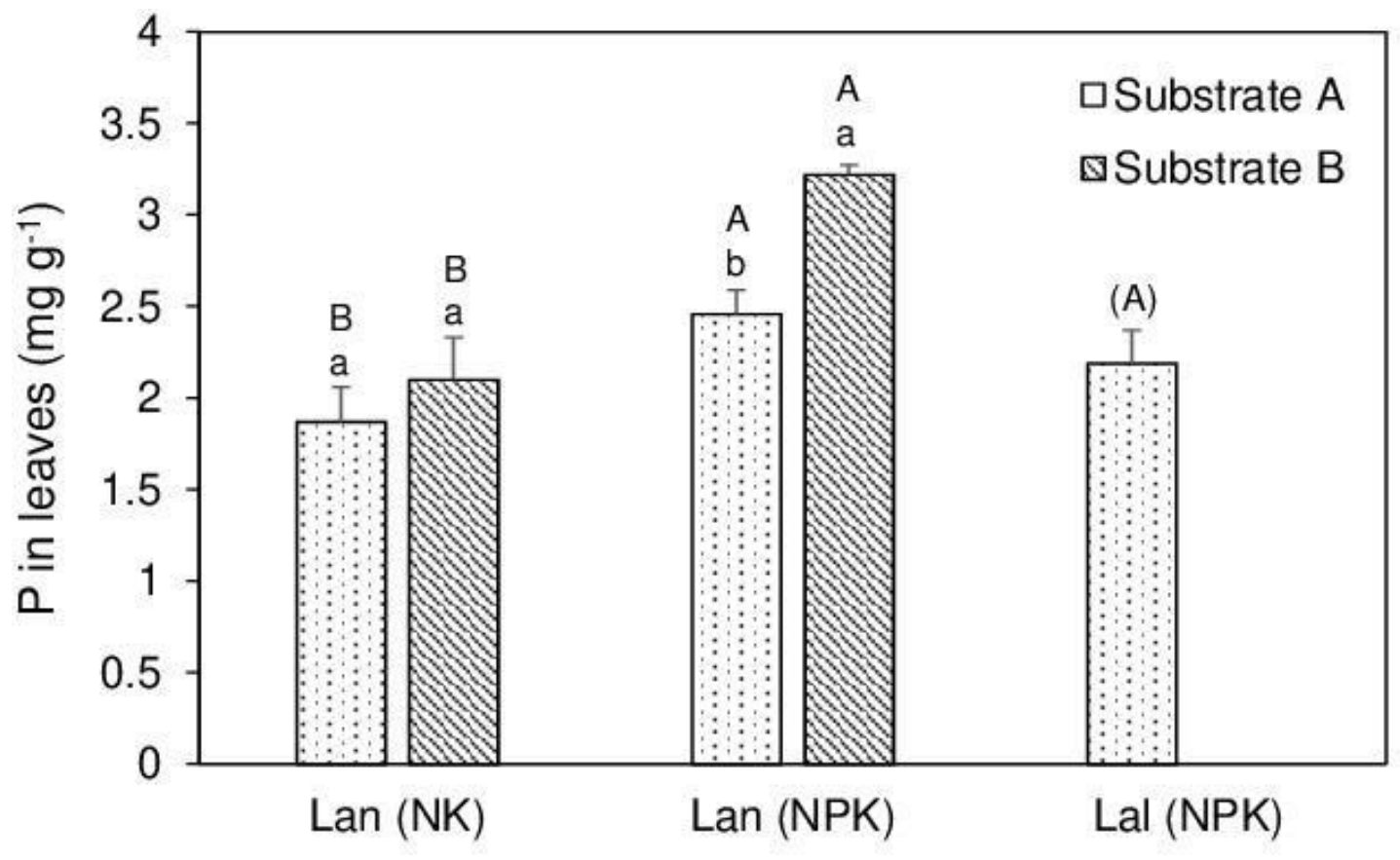

Figure 3

Leaf $\mathrm{P}$ concentrations in mixed cultured lupin plants (L. angustifolius: Lan, L. albus: Lal) that received fertilizer with low $\mathrm{P}$ doses $\left(1 \mathrm{~g} \mathrm{~m}^{-2}\right.$ : NK) or high doses of $\mathrm{P}\left(3 \mathrm{~g} \mathrm{~m}^{-2}\right.$ : NPK $)$. Means $\pm \mathrm{sd}(\mathrm{n}=4)$. Significant differences among means were identified by t-tests with Bonferroni adjustment. Small letters denote differences between the substrates within a certain P-treatment. Capital letters show differences in P-treatments within a specific substrate. Means with different letters are significantly different at $a=5 \%$. 